\title{
Recordings from Slices Indicate that Octopus Cells of the Cochlear Nucleus Detect Coincident Firing of Auditory Nerve Fibers with Temporal Precision
}

\author{
Nace L. Golding, Donald Robertson, ${ }^{\mathrm{a}}$ and Donata Oertel \\ Department of Neurophysiology, University of Wisconsin, Madison, Wisconsin 53706
}

Acoustic information in auditory nerve discharges is integrated in the cochlear nuclei, and ascends through several parallel pathways to higher centers. Octopus cells of the posteroventral cochlear nucleus form a pathway known to carry information in the timing of action potentials. Octopus cells have dendrites oriented to receive converging input from many auditory nerve fibers. In all 34 intracellular recordings from anatomically identified octopus cells in slices, shocks to the auditory nerve evoked brief, consistent, graded EPSPs. EPSPs were about $1 \mathrm{msec}$ in duration. At all but the lowest shock strengths, the delays between shocks and the peaks of resultant EPSPs had SDs of 0.02 msec. Polysynaptic excitation, perhaps arising from the axon collaterals of octopus cells, was observed. No detectable glycinergic or GABAergic inhibition was evoked with shocks. The input resistances were low, around $\mathbf{1 0}$ $M \Omega$, voltage changes were rapid, with time constants of about $1 \mathrm{msec}$, and action potentials were small. The low input resistance resulted in part from a $\mathrm{Cs}^{+}$-sensitive conductance. In the presence of 10 or $15 \mathrm{~mm}$ extracellular $\mathrm{Cs}^{+}$ the time constants increased 20 -fold in the hyperpolarizing voltage range.

As several subthreshold inputs were required to produce suprathreshold responses, octopus cells detect the coincident firing of auditory nerve fibers. Under physiological conditions the low input resistance and resulting short time constant limit the time over which temporal summation of excitation from auditory nerve fibers can occur and thus provide temporal precision to electrical signaling.

[Key words: auditory pathways, brain slices, intracellular recordings, cochlear nuclei, hearing, inward rectifier]

Received July 13, 1994; revised Oct. 24, 1994; accepted Nov. 3, 1994

We are grateful to Dan Geisler for suggesting and making possible this intercontinental collaboration and for reading the manuscript. Thanks also to Inge Siggelkow, Jo Ann Eckleberry, Joan Meister, Carol Dizack and Terry Stewart for expert and unflagging technical assistance, and to John Brugge and Pat Heinritz for administrative support. Phil Smith and Philip Joris shared with us their results and their thoughts when the tentacles of our research entwined in the octopus cell area. We thank Larry Trussell for reading and criticizing the manuscript. The work was supported by grants from NIH, RO1 DCO0176 and PO1 DC00116. Don Robertson was also supported by a study leave grant from The University of Western Australia. Nace Golding was supported by a graduate fellowship from NSF.

Correspondence should be addressed to D. Oertel, Department of Neurophysiology, University of Wisconsin, 1300 University Avenue, Madison, WI 53706 .

"Present address: The Auditory Laboratory, Department of Physiology, The University of Western Australia, Nedlands, Western Australia, WA 6009, Australia.

Copyright (C) 1995 Society for Neuroscience $\quad 0270-6474 / 95 / 153138-16 \$ 05.00 / 0$
The octopus cells lie in an area defined by a discrete border in the most caudal and dorsal posteroventral cochlear nucleus in mammals (Osen, 1969; Kane, 1973; Brawer et al., 1974; Disterhoft, 1980; Webster and Trune, 1982; Rhode et al., 1983; Willard and Ryugo, 1983; Adams, 1986; Hackney et al., 1990; Morest et al., 1990; Oertel et al., 1990; Willott and Bross, 1990; Wickesberg et al,, 1991). Their axons travel through the intermediate acoustic stria to terminate contralaterally in the dorsomedial periolivary nucleus and in the ventral nucleus of the lateral lemniscus, forming one of the major ascending auditory pathways (Warr, 1969, 1972, 1982; Adams and Warr, 1976; Joris et al., 1992; Smith et al., 1993).

Octopus cells seem to trade tuning for timing. Most parts of the cochlear nuclei of mammals are organized so that a tonotopically arranged population of cells encodes the hearing range as a whole, each cell encoding only a limited frequency range (Rose et al., 1959). Auditory nerve fibers innervate isofrequency laminae that stack to form a topographic representation of frequency (Osen, 1970; Blackstad et al., 1984; Wickesberg and Oertel, 1988; Leake and Snyder, 1989; Brown and Ledwith, 1990; Berglund and Brown, 1993). Individual target cells receive input from a restricted group of auditory nerve fibers and are tuned to a narrow range of frequencies. The organization of the octopus cell area is different. There auditory nerve fibers are closely bundled; the large dendrites of octopus cells extend across the fibers, poised to receive converging input from fibers emanating from wide regions of the cochlea (Osen, 1969; Kane, 1973). As expected from such an anatomical arrangement, octopus cells in vivo are broadly tuned and are between $20 \mathrm{~dB}$ to $50 \mathrm{~dB}$ less sensitive to tones than other cells in the ventral coch lear nucleus (Godfrey et al., 1975; Rhode and Smith, 1986; Joris et al., 1992). There are few octopus cells, only about 200 in the PVCN of a mouse (Willott and Bross, 1990), so that any spatial map, such as a tonotopic map, necessarily has limited resolution in the octopus cell area. The responses of octopus cells to sound are remarkable for the precision in timing in encoding the onset of tones and clicks (Godfrey et al., 1975; Romand, 1978; Rhode et al., 1983; Rouiller and Ryugo, 1984; Rhode and Smith, 1986; Friauf and Ostwald, 1988; Joris et al., 1992; Smith et al., 1993; Feng et al., 1994).

With intracellular recordings we show that octopus cells are remarkably fast in vitro in concordance with their ability to encode timing with precision in vivo. They respond to shocks of the auditory nerve fibers with brief EPSPs that are consistent in their shape and timing. Octopus cells have unusually low input resistances that are mediated in part by a $\mathrm{Cs}^{+}$-sensitive conductance. These unusual electrical characteristics make octopus cells 
well suited to convey precise timing information contained in the firing of groups of auditory nerve fibers.

\section{Materials and Methods}

Slices of the cochlear nuclear complex were prepared from mice (CBA and BALB/C strains) ranging in age from 17 to $26 \mathrm{~d}$ after birth. No obvious differences were observed in the properties of octopus or other cells as a function of age or strain. Details of techniques have been published previously (Oertel, 1985; Zhang and Oertel, 1993a). Briefly, animals were decapitated and the brain was removed under oxygenated $\left(95 \% \mathrm{O}_{2}, 5 \% \mathrm{CO}_{2}\right)$ normal saline which contained $130 \mathrm{~mm} \mathrm{NaCl}, 3 \mathrm{~mm}$ $\mathrm{KCl}, 1.3 \mathrm{mM} \mathrm{MgSO}_{4}, 2.4 \mathrm{mM} \mathrm{CaCl}_{2}, 20 \mathrm{~mm} \mathrm{NaHCO}_{3}, 3 \mathrm{~mm}$ HEPES, $10 \mathrm{mM}$ glucose, $1.2 \mathrm{mM} \mathrm{KH}_{2} \mathrm{PO}_{4}$, pH 7.4.

Parasagittal or coronal slices $200-350 \mu \mathrm{m}$ thick were prepared using an oscillating tissue slicer (Frederick Haer). Slices were maintained in a chamber where they were submerged in rapidly flowing, oxygenated saline solution (Oertel, 1985). The flow rate of solution in the chamber ranged from 6 to $12 \mathrm{ml} / \mathrm{min}$ and the temperature adjacent to the slice was held between 33.8 and $34.1^{\circ} \mathrm{C}$. In a few of the experiments recordings were made from cochlear nuclei that were cut in their entirety from the brain stem with scissors (Zhang and Oertel, 1993a). These preparations were similar in size and shape as well as in their behavior to parasagittal slices and are thus lumped with parasagittal slices.

For delivery of different pharmacological agents during intracellular recording, the bathing solution was exchanged with the test solution without interruption of the flow. 4-Aminopyridine (4-AP) (Sigma), strychnine (Sigma), and 6,7-dinitroquinoxaline-2,3-dione (DNQX) (Tocris Neuramin), were simply added to the bathing solution. Tetraethyl ammonium chloride (TEA) (Sigma) and $\mathrm{CsCl}$ (Sigma) were substituted for an equal concentration of $\mathrm{NaCl}$.

To activate auditory nerve fibers, shocks were delivered to the cut end of the auditory nerve. Stimulating electrodes, a pair of fine tungsten wires, insulated except at their $50 \mu \mathrm{m}$ diameter tips, were placed on the nerve root and voltage pulses of $100 \mu \mathrm{sec}$ duration were delivered through optical stimulus isolators at amplitudes ranging from 0.1 to 100 $\mathrm{V}$ at rates ranging from $0.1 / \mathrm{sec}$ to $1000 / \mathrm{sec}$. Intracellular recordings were obtained using glass microelectrodes. Electrodes were generally filled with $1 \%$ biocytin (Sigma) in $2 \mathrm{M}$ potassium acetate; the electrodes had resistances from 120 to $200 \mathrm{M} \Omega$ In two experiments electrodes were filled with $2 \mathrm{M} \mathrm{CsCl}$ and $1 \%$ biocytin. Membrane potential was monitored throughout the experiment on a chart recorder. In some experiments, records of physiological responses of cells were photographed directly from an oscilloscope; in others responses were digitized and stored on a Northgate 486 computer using pCLAMP software (Axon Instruments). For some of the digitally recorded responses, measurements were made of latencies between the beginning of the shock artifact to the pcak of the synaptic response. For such mcasurements, responses were sampled at 3 or $8 \mu \mathrm{sec}$, the maximum possible rates with the Digidata and TL-1 DMA interfaces, respectively. For measurement of time constants, the digitized records were fit with two exponentials with the Simplex routine provided in the pCLAMP (version 6) software package.

To label cells during impalement, biocytin was ejected from the electrode using 1-2 nA depolarizing current pulses of $200 \mathrm{msec}$ duration delivered at a rate of $2.5 / \mathrm{sec}$ for up to $5 \mathrm{~min}$. One or two cells per slice were labeled and their locations marked on a drawing of the slice. In one slice, an extracellular injection of biocytin was also made in the root of the auditory nerve. This injection was made by applying 25 pressure pulses, $15 \mathrm{psi}, 150 \mathrm{msec}$ duration to the back of a pipette filled with $2 \%$ biocytin and having a diameter of $17 \mu \mathrm{m}$. Slices were fixed in $4 \%$ paraformaldehyde in $0.1 \mathrm{M}$ phosphate buffer $(\mathrm{pH} 7.4)$ for periods ranging from $24 \mathrm{hr}$ to 2 weeks. They were embedded in a mixture of gelatin and albumin and sectioned either as frozen sections or on a vibratome at $60 \mu \mathrm{m}$. The sections were reacted with avidin conjugated to horseradish peroxidase (Vector $\mathrm{ABC}$ kit) (Horikawa and Armstrong, 1988; King et al., 1989), and processed for horseradish peroxidase (Wickesberg and Oertel, 1988) using $\mathrm{Co}^{2+}$ and $\mathrm{Ni}^{2+}$ intensification (Adams, 1981). Sections mounted on coated slides were counterstained with cresyl violet. The cells as well as the slices were reconstructed with a camera lucida. Each of the labeled octopus cells has been given a number that is used consistently throughout the article.
Table 1. Labeled octopus cells

\begin{tabular}{|c|c|c|c|c|c|}
\hline \multirow[b]{2}{*}{ Cell } & \multirow[b]{2}{*}{ Date } & \multirow{2}{*}{$\begin{array}{l}\text { Age } \\
\text { (d) }\end{array}$} & \multicolumn{3}{|c|}{ Collaterals } \\
\hline & & & $\mathrm{Gr}$ & OCA & $\mathrm{DCN}$ \\
\hline 1 & $8-29-91 \mathrm{C}$ & 22 & + & + & - \\
\hline 2 & $2-17-92 A$ & 21 & + & + & - \\
\hline 3 & $3-26-92 \mathrm{C}$ & 23 & + & + & - \\
\hline 4 & $8-30-91 \mathrm{C}$ & 23 & + & + & + \\
\hline 5 & $11-21-91 G$ & $?$ & + & + & - \\
\hline 6 & $5-11-94 \mathrm{~A}$ & 23 & & Short axon & \\
\hline 7 & $11-7-91 \mathrm{C}$ & $?$ & & None & \\
\hline 8 & $6-2-92 \mathrm{~A}$ & 19 & + & - & $?$ \\
\hline 9 & $5-7-92 B$ & 22 & & Light & \\
\hline 10 & $8-6-91 E$ & 23 & & Light & \\
\hline 11 & $2-7-92 \mathrm{~A}$ & $?$ & & Short axon & \\
\hline 12 & $6-2-93 C$ & 24 & & Short axon & \\
\hline 13 & $11-6-91 B$ & 24 & & Short axon & \\
\hline 14 & $11-19-91 \mathrm{~B}$ & $?$ & & Light & \\
\hline 15 & $2-2-93 \mathrm{~A}$ & 21 & & + & + \\
\hline 16 & $10-10-91 \mathrm{~B}$ & 17 & & Short axon & \\
\hline 17 & $6-23-92 B$ & 20 & & Light & \\
\hline 18 & $6-16-93 \mathrm{C}$ & 21 & + & + & - \\
\hline 19 & $11-21-91 \mathrm{~F}$ & $?$ & + & + & + \\
\hline 20 & $2-18-94 \mathrm{~A}$ & 21 & & Light & \\
\hline 21 & $3-7-94 \mathrm{~A}$ & 23 & & Short axon & \\
\hline 22 & $3-16-94 \mathrm{~A}$ & 18 & & Short axon & \\
\hline 23 & $4-12-94 \mathrm{~A}$ & 20 & & Light & \\
\hline 24 & $10-22-91 \mathrm{C}$ & 23 & & None & \\
\hline 25 & $3-22-90 \mathrm{~A}$ & 18 & & Light & \\
\hline 26 & $5-27-93 C$ & 20 & + & + & - \\
\hline 27 & $6-14-93 C$ & 19 & & Light & \\
\hline 28 & $10-18-91 E^{*}$ & 19 & + & - & - \\
\hline 29 & $2-22-94 B$ & 25 & + & + & - \\
\hline 30 & $12-1-93 B$ & 23 & - & + & - \\
\hline 31 & $12-14-93 B$ & 20 & - & + & - \\
\hline 32 & $3-3-94 A$ & 21 & & Short axon & \\
\hline 33 & $3-9-94 B$ & 20 & $?$ & + & + \\
\hline 34 & $3-15-94 B$ & 17 & & Light & \\
\hline 35 & 3-24-94D & 26 & + & + & - \\
\hline
\end{tabular}

Each labeled cell has been assigned a number that is given in the left column. The date of the experiment and the age in postnatal days are shown in the next two columns. The last three columns show the locations of terminal boutons of collaterals of octopus cell axons. The asterisk denotes a cell from which no electrophysiological records were saved.

\section{Results}

The results reported here are based on recordings from 35 anatomically identified octopus cells in 34 slices. Intracellular recordings could be clearly attributed to the labeled octopus cells in 34 cases (Table 1). Recordings from cells other than octopus cells resembled recordings reported in other publications (Wu and Oertel, 1984; Oertel et al., 1990; Zhang and Oertel, 1993ac, 1994). All reported results are from anatomically identified octopus cells.

\section{Morphology of octopus cells in mice}

Figure 1 shows one octopus cell (cell 2), labeled with an intracellular injection of biocytin, in a slice in which a few auditory nerve fibers had also been labeled extracellularly. The descending branches of auditory nerve fibers emanate from the nerve root and pass in fascicles through the multipolar cell and octopus 


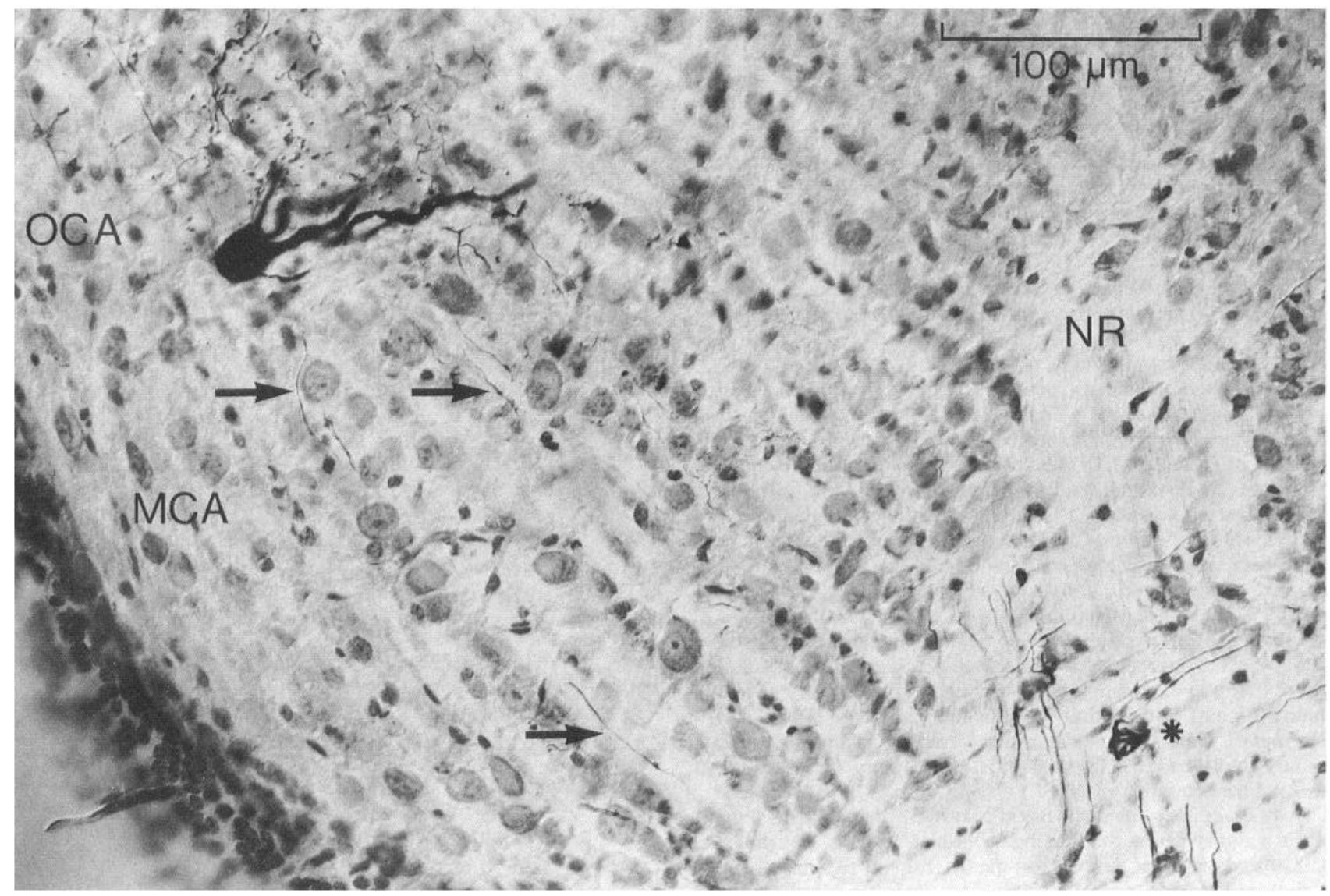

Figure 1. Photomicrograph of the section that includes the cell body of octopus cell 2. In this parasagittal slice an extracellular injection of biocytin had been made into the stump of the auditory nerve, outside the field of view, which labeled a few auditory nerve fibers. Auditory nerve fibers enter the nucleus ventrally and bifurcate in the nerve root $(N R)$ visible as a triangular area that contains few cell bodies. One branch of auditory nerve fibers passes caudally through the multipolar cell area $(M C A)$ to the octopus cell area $(O C A)$. The path of auditory nerve fibers is apparent not only from the labeled fibers (arrows) but also from the fiber fascicles that separate groups of cell bodies in the multipolar cell area. Octopus cell 2 has its dendrites oriented perpendicularly to the fascicles of fibers. One fiber forms an end bulb around a globular bushy cell in the nerve root (asterisk). Labeled boutons in the OCA include terminals of auditory nerve fibers and a few local collaterals of cell 2.

cell areas of the PVCN in their course caudally and dorsally to the dorsal cochlear nucleus (DCN). Fine sprays of terminal boutons spread diffusely in the octopus cell area, in contrast to the multipolar cell area where they cluster (not shown). One labeled octopus cell lies in the caudal PVCN. Characteristically, its thick dendrites cross the fascicles of auditory nerve fibers. Local collaterals of this cell lie intermingled among the terminals of auditory nerve fibers.

Reconstructions of six octopus cells are shown in Figures 2 and 3 . The counterstaining with cresyl violet showed that all the labeled cells lay in the caudal PVCN among other Nissl-stained octopus cells, recognizable by their large size and their homogeneously granular staining pattern. The dendrites remained thick to near their ends where they branched. In some densely labeled cells, clusters of somatic and proximal dendritic spines were visible. In 9 of the 35 cells, the biocytin labeling was too light to reveal the fine details of the dendritic and axonal arborizations.

Many octopus cells in mice had local axon collaterals in the cochlear nuclei. As octopus cells are projecting cells, their large axons, between 2 and $4 \mu \mathrm{m}$ in diameter, were invariably cut in slices. In most of the 16 cells in which the axons could be traced for $300 \mu \mathrm{m}$ or more in their course dorsally and medially, toward or into the intermediate acoustic stria, collaterals branched from the main axon to terminate in the cochlear nuclei. Commonly, collaterals terminated in adjacent granule cell regions and in the octopus cell area. Of the 16 octopus cells, 12 had collateral terminals associated with granule cells in the vicinity of the octopus cell area (Fig. $4 A-E$ ). Terminals were observed among granule cells, in the granule cell lamina, in the superficial granule cells that cover the lateral surface of the octopus cell area, and occasionally among granule cells of the medial sheet (Mugnaini et al., 1980). The terminals in the granule cell regions varied in size between about 2 and $5 \mu \mathrm{m}$ in diameter. Of those same 16 octopus cells, 14 terminated within the octopus cell area. Terminal swellings of variable size were observed within the octopus cell area, in some cases intermingled with the cell's own dendrites. The terminals of cell 19 were so close to the parent soma and one of the dendrites that the cell may have terminated upon itself (Figs. 3, $4 G$ ). Less commonly, in 3 of 16 cells, collaterals terminated in the deep layer of the DCN (Table 1).

\section{Synaptic responses to shocks of the auditory nerve}

Shocks to the auditory nerve evoked EPSPs in all octopus cells. Synaptic responses to shocks from 18 different, anatomically identified, octopus cells are shown in Figure 5. Responses were consistent among octopus cells. In every cell responses were 


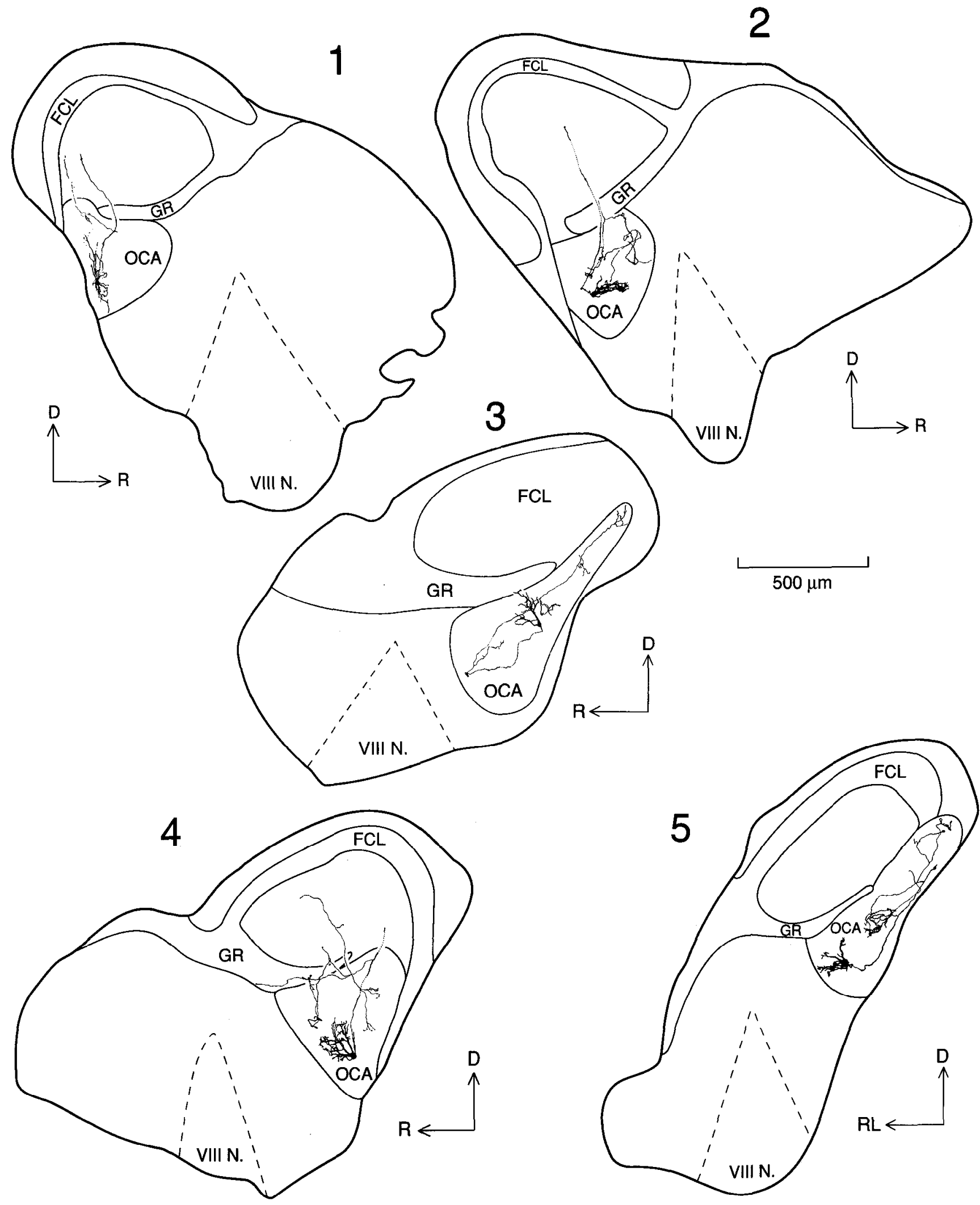

Figure 2. Reconstructions of five octopus cells labeled by the intracellular injection of biocytin in parasagittal slices. Reconstructions of octopus cells are shown in reconstructions of the slices. Each of the octopus cells had collateral terminals in the cochlear nuclei. Terminal boutons lay in the octopus cell area, the granule cell lamina, the superficial granule cells or the deep layer of the DCN. Slices were cut approximately parasagittally. The drawings were made to show as clearly as possible the location of octopus cells and their collaterals with respect to the architecture of the cochlear nuclei. Generally the fusiform cell layer $(F C L)$ in the DCN and the granule cell lamina $(G R)$ are indicated from sections that contained the cell bodies. The root of the auditory nerve is indicated with the dashed lines (VIIIN). 

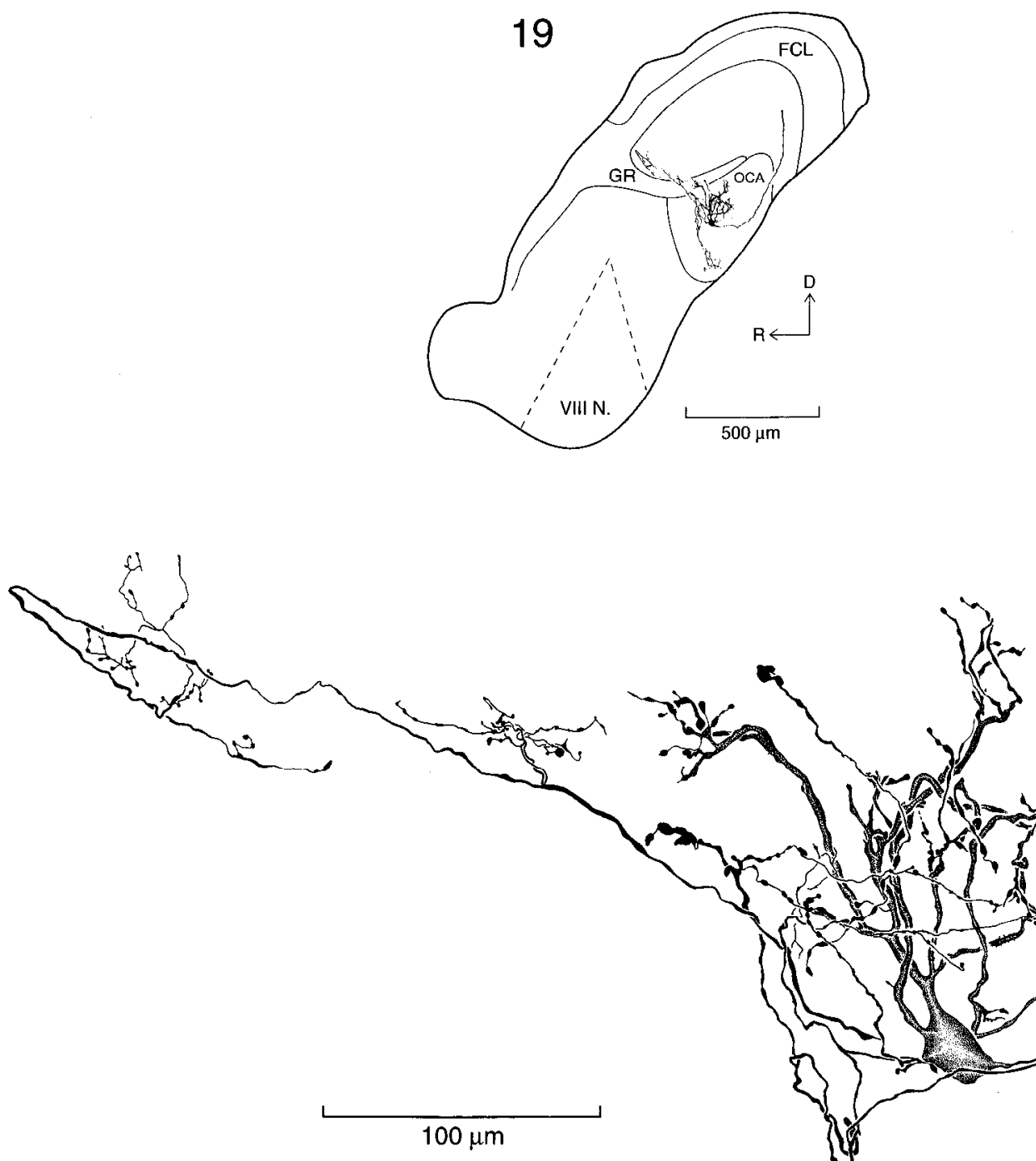


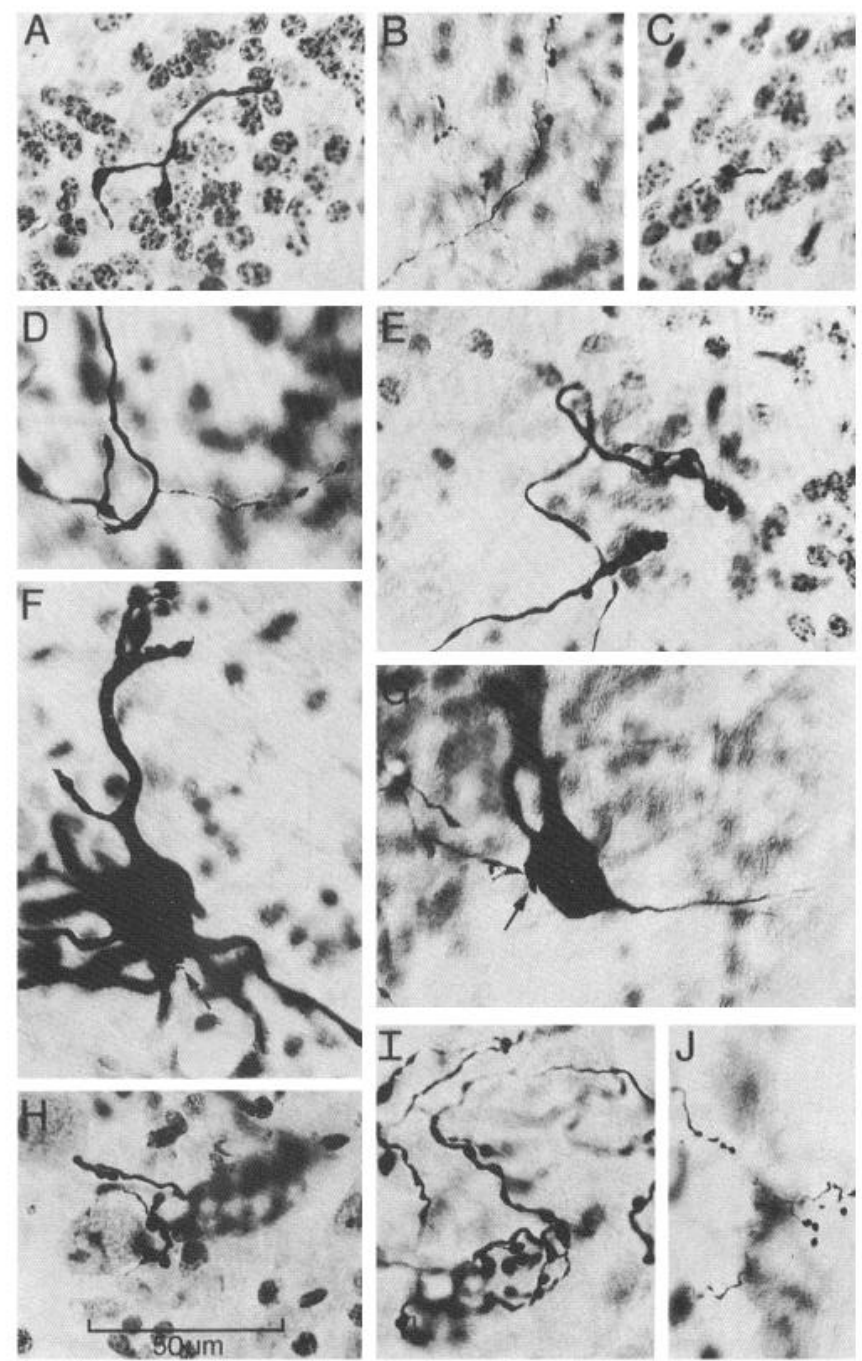

Figure 4. Photomicrographs of some of the labeled octopus cells. A$E$, Terminals of four labeled octopus cells associated with granule cells. Some of the terminals are large $(A, D, E)$; others are smaller $(B-D)$. Granule cells were visualized with Nissl staining or with Nomarski optics. $A$ and $D$, cell $2 ; B$, cell $3 ; C$, cell $8 ; E$, cell 5 . $F$, Cell body of cell 5 has spines in one area (arrow). $G$, Collaterals of cell 19 terminate in the vicinity of its own cell body (arrow). $H-J$, Terminals of octopus cells in the octopus cell area. $H$, cell $5 ; I$, cell $5 ; J$, cell 19 .

brief and graded as a function of shock strength. In most cells the depolarizing phases of the responses lasted about $1 \mathrm{msec}$; including the afterhyperpolarization that followed the depolarizing phases, responses lasted about $3 \mathrm{msec}$. In some synaptic responses an inflection could be detected in the synaptic responses (Fig. 5, cells 2, 3, 4, 5, 9, 14, 16, 18). This probably reflects an action potential that is generated at an electrically distant site, which sums in its attenuated form with the more locally generated EPSP.

The relationship between stimulus voltage and response was examined in detail in three cells (Fig. 6). The shape of plots of stimulus strength and response amplitude varied from cell to cell but in all cases was monotonic. Presumably more and more of the auditory nerve fibers that converge on the impaled octopus cells were brought to threshold as the shock strength was increased. The fact that the amplitude of responses was graded with shock strength over a wide range indicates that octopus cells received converging input from many auditory nerve fibers, each fiber contributing a small increment to the response. The plots of the amplitudes of responses as a function of shock strength for each of the cells showed a discontinuity that was associated with the appearance of what we interpret to be a small, all-or-none action potential in the synaptic responses. The discontinuity was most clearly seen in responses evoked by weak shocks in which the inflection followed the rising phase of the EPSP and was more obvious in the responses of cell 20 than in those of cell 6 . The action potential was clearest in responses that were barely suprathreshold, in which the rising phase of the EPSP occurred before the rising phase of the action potential and gave the response an inflection. The asterisks in the three upper plots of Figure 6 indicate the amplitudes of responses near threshold; the dots to the left of the trace in the bottom panels indicate the threshold of action potentials and the associated inflection in the voltage change. With stronger stimuli, the inflections occurred earlier and became continuous with the rising phases of the EPSPs. In each of the three cells, responses below threshold were graded in amplitude, indicating that the summing of several inputs was required to bring the cells to threshold. When the inputs were activated synchronously with shocks, only a small proportion of the cells' inputs were required to bring the cells to threshold. The duration of responses reflects the time period over which auditory nerve inputs can interact. Because synaptic responses are brief, and because the summing of several inputs is required to produce an action potential, octopus cells are effective as coincidence detectors of auditory nerve inputs.

Responses of octopus cells to shocks of the auditory nerve were consistent in their shape and timing. Figure 7 shows synaptic responses of cell 12 to shocks of four different intensities delivered to the auditory nerve at a rate of $1 / \mathrm{sec}$. Measurements of jitter in timing were made from 60 responses at each intensity. The mean latency to peak was longer $(1.14 \mathrm{msec})$ and more variable $(0.04 \mathrm{msec}$, standard deviation) in responses to weak shocks than in responses to strong shocks $(1.02 \pm 0.02 \mathrm{msec})$. Jitter in latency for eight cells at various shock strengths is summarized in Table 2. The table reveals clear trends. Weak shocks produced responses with variable latencies; for a wide range of stronger shocks, the standard deviation of the latency was 0.02 msec. Some of the variability in responses could have arisen from the variability in the number and timing of the activation of auditory nerve fibers by weak shocks. Presumably the timing of action potentials that are embedded in the peaks of synaptic responses is similar in its precision to the timing of the peaks of the large synaptic responses.

The precision in the timing of firing in responses to shocks delivered at low rates raises the question whether such precision can be maintained when auditory nerve fibers are stimulated at physiological rates. Auditory nerve fibers fire up to about 300/ sec in responses to tones in cats (Sachs and Abbas, 1974). In three labeled octopus cells we measured the synaptic responses to trains of shocks to the root of the auditory nerve. One series is illustrated in Figure 8. EPSPs in cell 5 followed shocks at high frequencies. When this cell was stimulated at $244 / \mathrm{sec}$, responses showed little decrement in amplitude and no detectable change in latency to peak in successive responses. These results indicate that octopus cells convey with precision the averaged timing of firing of a population of auditory nerve fibers over the physiological range of firing rates of auditory nerve fibers. When shocks were presented at higher rates synaptic responses showed 

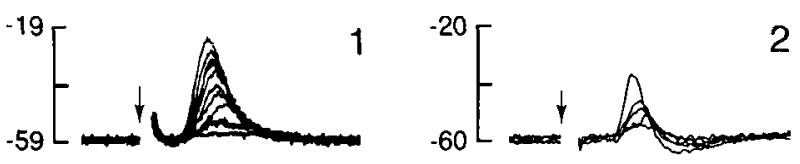

2
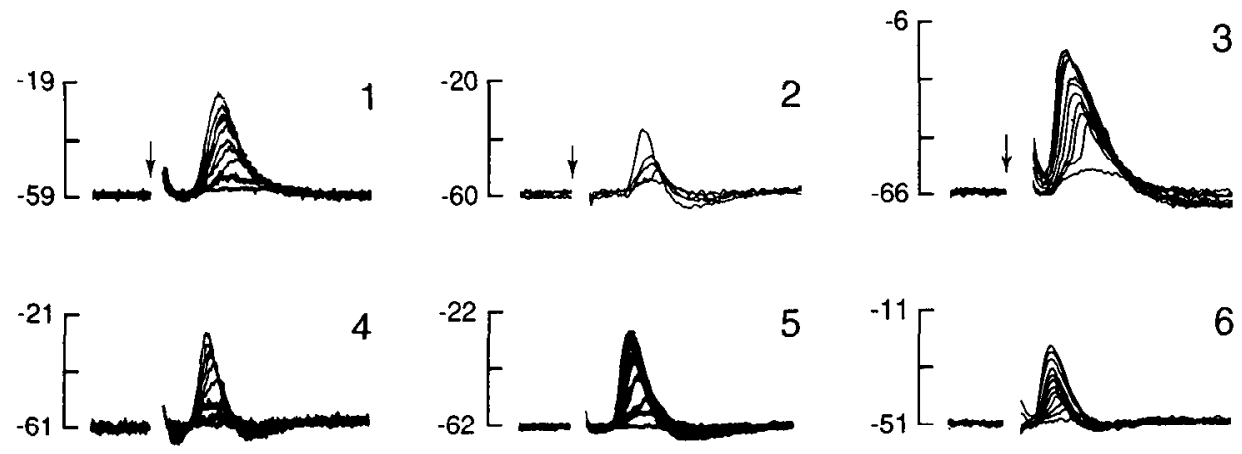

5

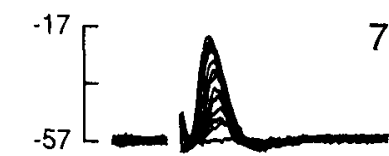

7

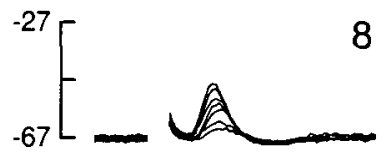

8

E
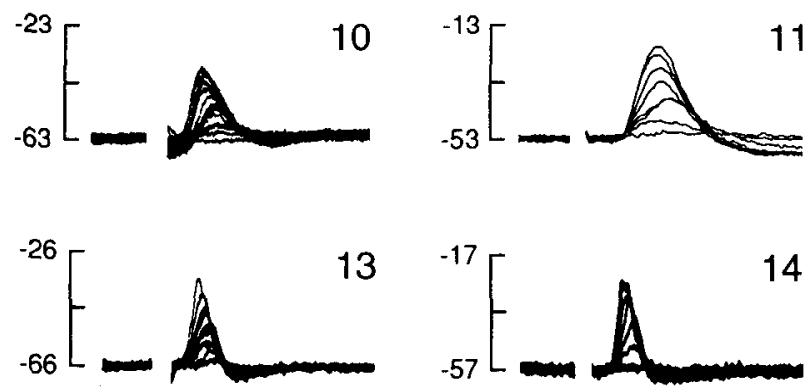

Figure 5. Synaptic responses to shocks to the auditory nerve of each of 18 intracellularly labeled octopus cells. Each panel shows superimposed responses to shocks of variable strength, illustrating the brief, graded synaptic responses characteristic of octopus cells. The gradedness of responses reflects variability in the number of activated auditory nerve fiber inputs. The numbers of cells correspond to the numbers in other figures.

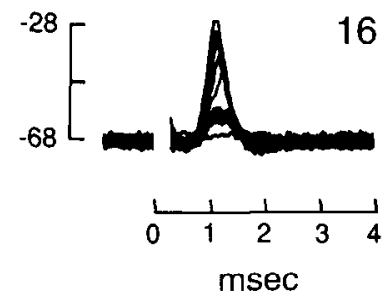

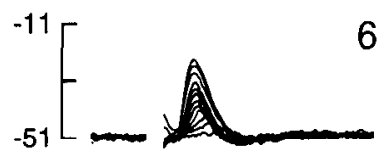
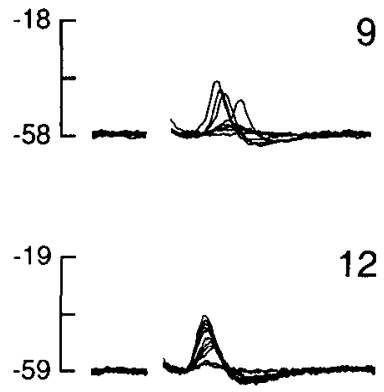

3

6

9

2

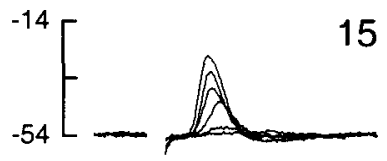

18

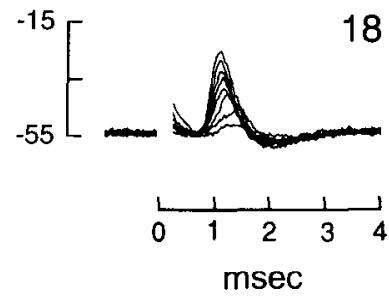

a decrement in amplitude of both the peak and afterhyperpolarization. The cell responded robustly to each shock even at 714/ sec. When octopus cells were stimulated rapidly, the timing of the peaks of responses also changed systematically. Stimulating the auditory nerve at rates higher than $244 \mathrm{~Hz}$ resulted in a progressive increase in the latency to the peak of the response in successive responses. The latency to peak of the fourth response at $476 \mathrm{~Hz}$ was $0.18 \mathrm{msec}$ greater than to the first; the eighth response in a train of shocks at $714 \mathrm{~Hz}$ was $0.30 \mathrm{msec}$ longer than the first.

\section{Polysynaptic responses}

In most octopus cells no late synaptic responses werc detceted (Fig. 5) but in four cells multiple EPSPs were recorded (Fig. 9). In some cells the late responses were consistently detectable (cell 19; trace not shown, cells 29, 31) while in another the late responses were weak and appeared sporadically (cell 15). Peaks of late EPSPs followed between 0.75 and $1.1 \mathrm{msec}$ after the peaks of early EPSPs in each of these cells. The late EPSPS could represent disynaptic responses through collaterals of other octopus cells, the only cochlear nuclear neurons of mice demonstrated to terminate in the octopus cell area.

IPSPs were not recorded in any octopus cell. No obvious IPSPs were detected in synaptic responses to shocks of the auditory nerve. As it was possible that the afterhyperpolarization that follows EPSPs could obscure IPSPs, we tested whether antagonists of inhibitory neurotransmitters produced any changes in the shapes of synaptic responses in two cells. Picrotoxin ( 100 $\mu \mathrm{M})$ and strychnine $(1 \mu \mathrm{M})$, blockers of GABA $\mathrm{A}_{\mathrm{A}}$ ergic and glycinergic inhibition, respectively, in other cells of the cochlear nuclei (Oertel and Wickesberg, 1993) as elsewhere (Choi and Fischbach, 1981), did not alter the shapes of synaptic responses of cells 4 (not shown) and 12 (Fig. 10). These negative results are not the consequence of inaccessibility of drugs to the cell because $40 \mu \mathrm{M}$ DNQX blocked the synaptic response in cell 12 . IPSPs could also not be revealed chemically with potassium channel blockers. In nine experiments slices were bathed in TEA, and/or 4-AP. Upon application, these agents produced barrages of synaptic potentials, presumably because presynaptic cell bodies and terminals fired spontaneously. In contrast with all 
6
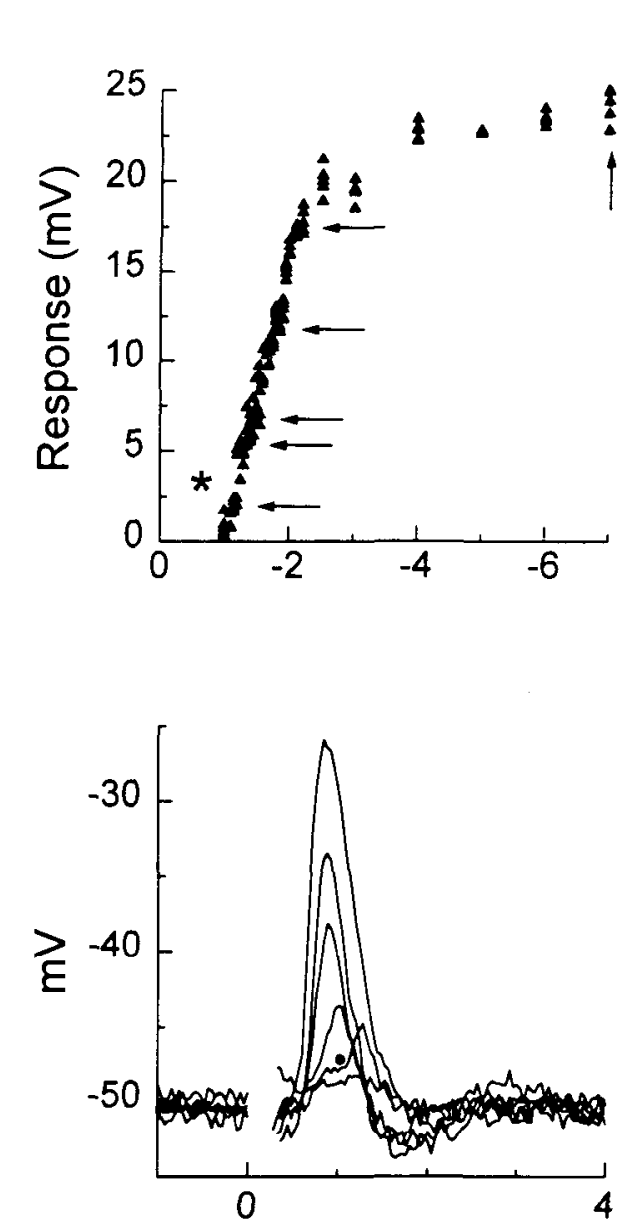

20
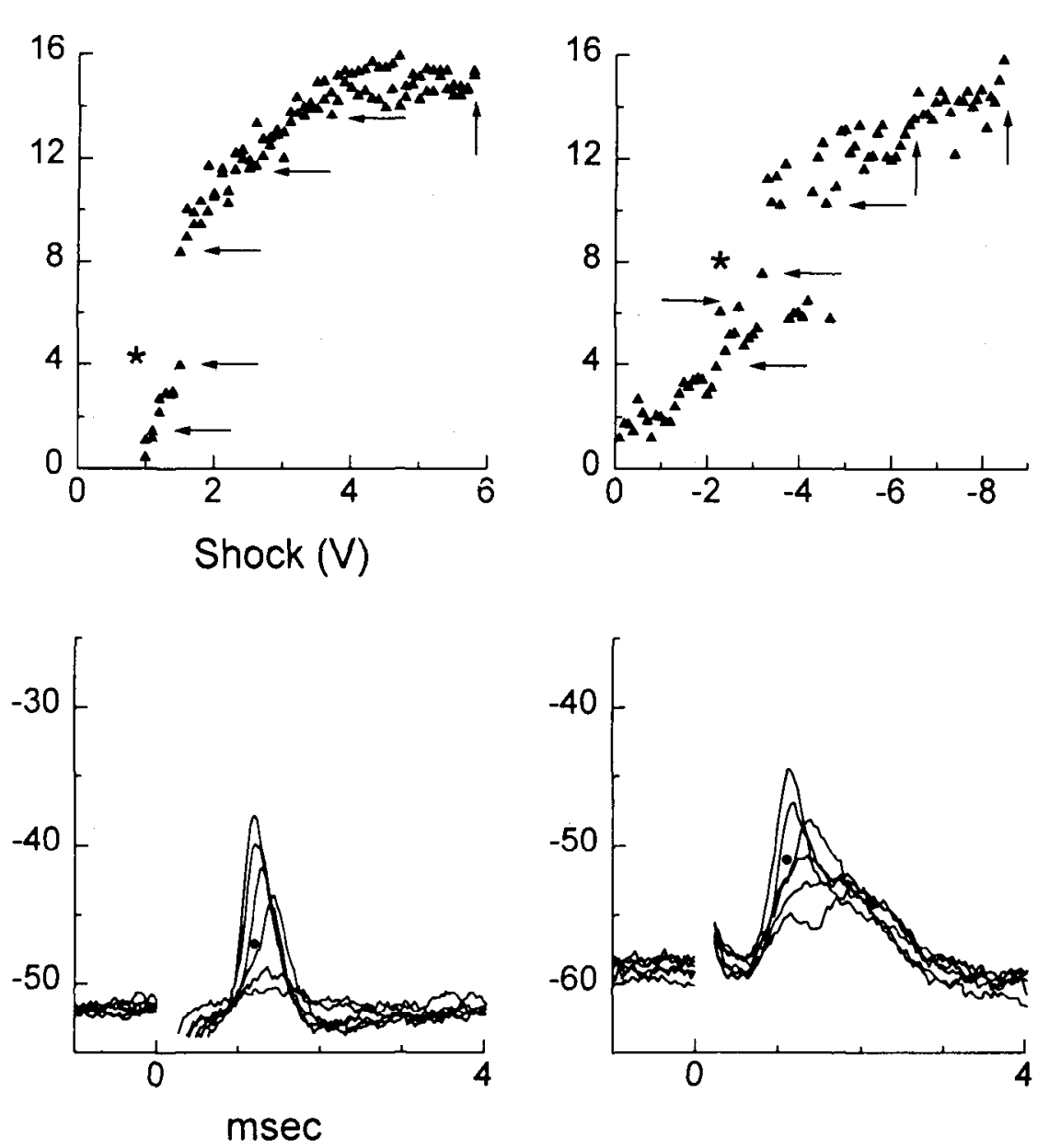

31

Figure 6. Amplitude of synaptic responses of labeled octopus cells as a function of shock strength. For cells 6, 20, and 31 response amplitude is plotted as a function of shock strength in the upper panels. Cell 31 had an early and a later response; the plot is of the amplitude of the early response. Six of the responses, marked with arrows, are shown in the traces below. Both the asterisks and the dots indicate the threshold of action potentials. Asterisks in the upper panels indicate the lower end of the discontinuity in the relationship. Dots at the left of one trace in each of the lower panels mark the inflections in the synaptic responses that reveal the thresholds of action potentials.

other cell types tested in the cochlear nuclei, the spontaneous synaptic potentials in octopus cells were exclusively EPSPs. These results are consistent with the conclusion that octopus cells are not contacted by inhibitory interneurons in the cochlear nuclear complex.

\section{EPSPs are mediated through glutamate receptors}

DNQX is a blocker of glutamate receptors of the AMPA subtype (Honoré et al., 1988). Figure 10 illustrates the sensitivity of EPSPs in cell 12 to DNQX. DNQX $(40 \mu \mathrm{M})$ blocked synaptic responses in all seven cells tested.

\section{Intrinsic electrical properties}

Action potentials recorded from octopus cells in slices were consistently small, between 5 and $10 \mathrm{mV}$. All-or-none action potentials could be evoked at the onset of depolarizing current pulses and at the offset of hyperpolarizing pulses in some, but not all, cells in normal saline. In the presence of potassium channel blockers, single action potentials were evoked at the onset of depolarizing current pulses in all cells tested, indicating that our inability to evoke action potentials in some cells in normal saline probably resulted from an inability to pass large currents through our microelectrodes and providing support for the interpretation that action potentials are generated at a site that is electrically distant from the cell body. Shocks to the auditory nerve often evoked small, all-or-none increments in synaptic responses that we interpret to be action potentials. The size of action potentials evoked with current was similar to the size of the action potentials detected in synaptic responses near threshold. The small size of the action potential was not the result of the cutting of the axon because there was no relationship between the presence of long segments of axons and collaterals and the presence of action potentials. The small size and high threshold of action potentials in octopus cells to injected current is consistent with their being generated at a site electrically more distant from the electrode than in other anatomical cell types. In similar slices of the cochlear nuclei we have recorded large action potentials in three types of stellate, fusiform, cartwheel, giant, and tuberculoventral cells (Wu and Oertel, 1984; Oertel and Wu, 1989; Oertel et al., 1990; Zhang and Ocrtel, 1993a-c; Zhang and Oertel, 

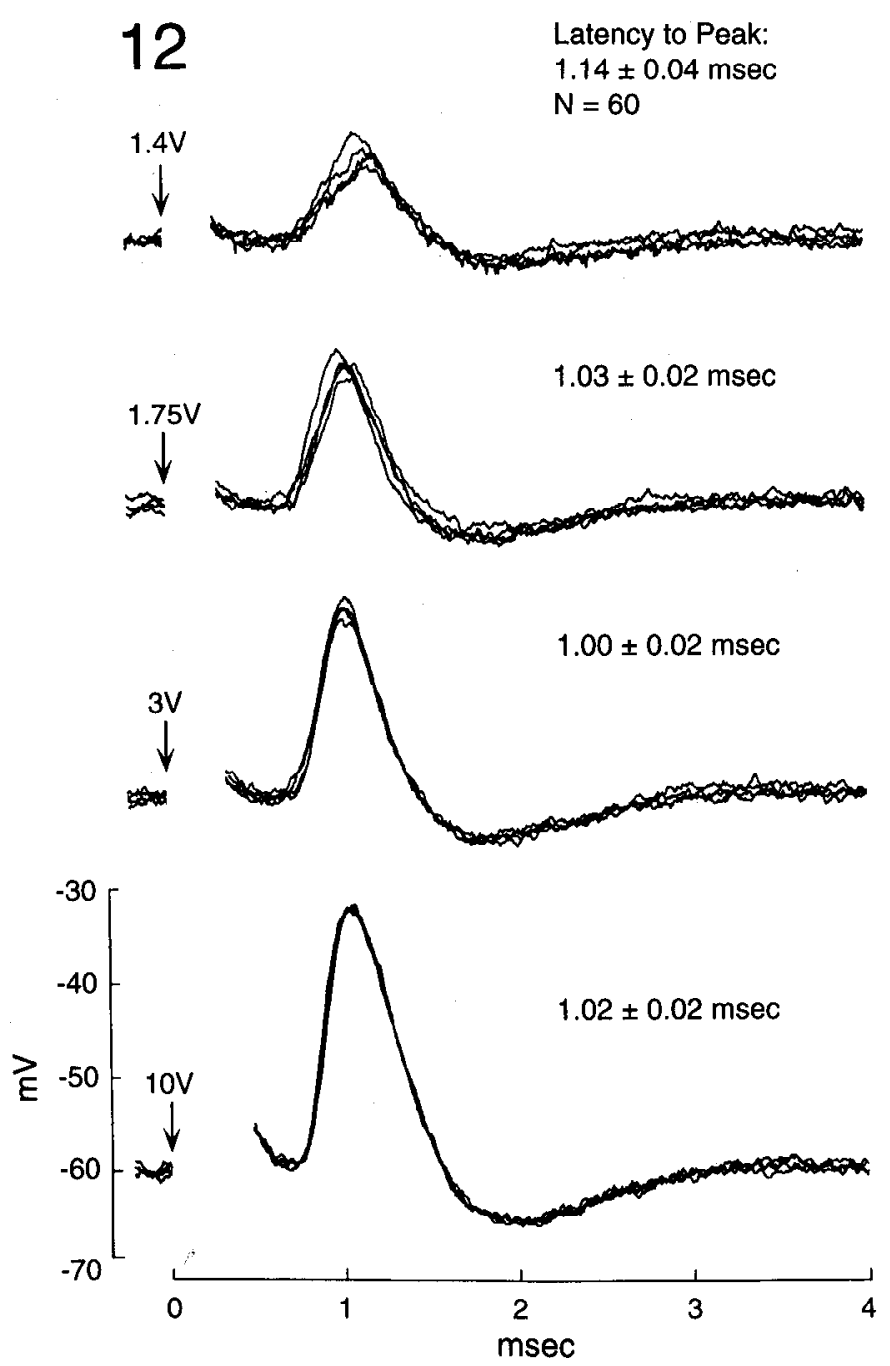

Figure 7. Timing to strong shocks is more precise than to weak shocks to the auditory nerve. Sixty responses, of which four are shown superimposed, were recorded for each shock strength in cell 12 . The numbers above the traces and on the right indicate the mean and SD of the latency, measured from the beginning of the shock artifact to the peak of the response.

1994). Nlthough the morphology of octopus cell axons is not obviously different from axons of other types of cells in the cochlear nuclei, a low input resistance presumably causes the axon hillock to be electrically more distant in octopus cells than in other neurons of the cochlear nuclei.

The input resistance was low in every recording from an octopus cell. It was not possible to use measures of the amplitudes of voltage changes in responses to current pulses to obtain estimates of input resistance because the time constants of the microelectrodes (between about 0.1 and $0.5 \mathrm{msec}$ ) were not sufficiently different from those of cells for the electrode contribution to the voltage change to be balanced. These results also raised the question whether the leakiness of octopus cells was an artifact of impalement or the result of the action of specific ion channels.

If the low input resistance of octopus cells resulted from the activity of channels in the membrane, then blockers of those channels should raise the input resistance. Thus, we measured the effects of known blockers of specific channels on the input resistance in 16 of the labeled octopus cells: tetraethyl ammo-
Table 2. Jitter in latency to peak of octopus cells

\begin{tabular}{|c|c|c|c|}
\hline \multirow[b]{2}{*}{ Cell } & \multirow[b]{2}{*}{ Voltage (V) } & \multicolumn{2}{|l|}{ Latency } \\
\hline & & Mean (msec) & $\mathrm{SD}(\mathrm{msec})$ \\
\hline \multirow[t]{4}{*}{12} & 1.4 & 1.14 & 0.04 \\
\hline & 1.75 & 1.03 & 0.02 \\
\hline & 3 & 1.00 & 0.02 \\
\hline & 10 & 1.02 & 0.02 \\
\hline \multirow[t]{3}{*}{15} & $8(\mathrm{AVCN})$ & 1.23 & 0.02 \\
\hline & $10(\mathrm{AVCN})$ & 1.22 & 0.01 \\
\hline & $40(\mathrm{AVCN})$ & 1.09 & 0.02 \\
\hline 18 & 6 & 1.12 & 0.02 \\
\hline \multirow[t]{4}{*}{20} & 1.5 & 1.30 & 0.06 \\
\hline & 2 & 1.23 & 0.02 \\
\hline & 4 & 1.15 & 0.02 \\
\hline & 5 & 1.20 & 0.02 \\
\hline \multirow[t]{4}{*}{23} & 7 & 1.20 & 0.05 \\
\hline & 9 & 1.17 & 0.04 \\
\hline & 10 & 1.03 & 0.02 \\
\hline & 30 & 1.00 & 0.02 \\
\hline 26 & 7 & 0.91 & 0.02 \\
\hline 27 & 5 & 1.15 & 0.02 \\
\hline \multirow[t]{3}{*}{29} & 1.5 & 1.30 & 0.05 \\
\hline & 3 & 1.23 & 0.03 \\
\hline & 10 & 1.03 & 0.02 \\
\hline
\end{tabular}

To measure the jitter in timing, latencies between the beginning of the shock artifact and the peak of the synaptic response were measured in 60 repetitions of identical shocks. The first column shows the numbers assigned to the labeled octopus cells. The second column indicates shock strength. In most cells shocks were to the nerve root. In one cell, where shocks are labeled (AVCN), shocks were presented to the ascending branch of the auditory nerve in the AVCN. The last two columns give the mean and SD of latencies

nium chloride (TEA), a blocker of $\mathrm{K}^{+}$conductances (Hille, 1967); 4-aminopyridine (4-AP), also a blocker of $\mathrm{K}^{+}$conductances (Yeh et al., 1976; Manis and Marx, 1991; Banks et al., 1993); and $\mathrm{Cs}^{+}$, a blocker of inward rectifiers (Hagiwara et al., 1976; McCormick and Pape, 1990; Banks et al., 1993; Kubo et al., 1993).

Neither the resting potential nor the input resistance of $4 \mathrm{oc}-$ topus cells, assayed by the injection of current, were measurably changed by the application of $15 \mathrm{mM}$ TEA in the bath. Potassium channels that are sensitive to TEA therefore make a relatively small contribution, if any, to the resting conductance.

Application of 4-AP produced changes in the properties of labeled octopus cells consistent with its known action on voltage-sensitive $\mathrm{K}^{+}$channels. When 4 -AP was applied at 1 or 2 $\mathrm{mM}$ it depolarized three labeled octopus cells and evoked a barrage of EPSPs, presumably by causing terminals of the inputs to fire (not shown). Even when excitatory input was blocked by $40 \mu \mathrm{M}$ DNQX, 1, 2, and $4 \mathrm{mM}$ 4-AP depolarized octopus cells by $8-10 \mathrm{mV}$ but did not cause a measurable change in the input resistance in three additional cells. Figure 11 illustrates the effects of $2 \mathrm{~mm}$ 4-AP on the resting potential and on action potentials of cell 21 . Anode-break action potentials are illustrated because, in occurring after the end of the current pulses, their measurement is independent of bridge balance. The action potentials evoked with depolarizing pulses were similarly broadened (not shown). The peaks of the action potentials in the presence of 4-AP reach more depolarized levels. Also, action 


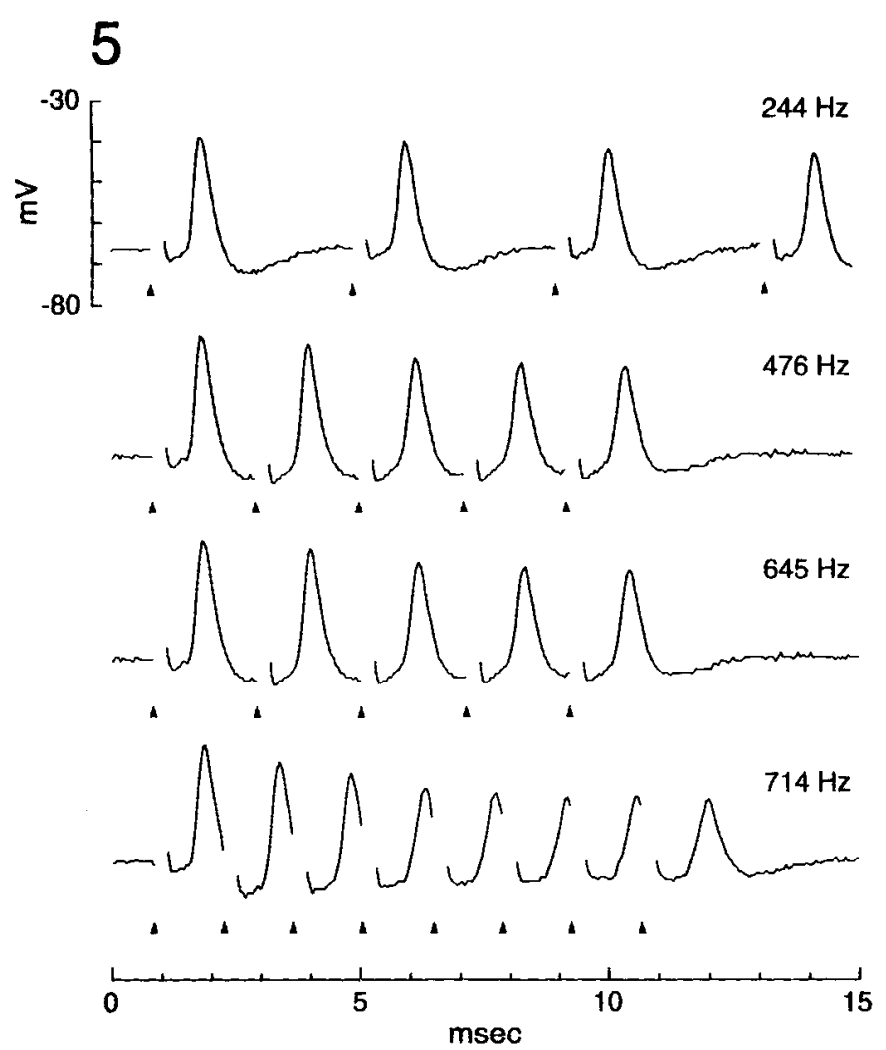

Figure 8. Responses to trains of shocks in cell 5. Shocks of $10 \mathrm{~V}$ were delivered to the auditory nerve at varying rates. Litlle decrement in amplitude was observed in responses to shocks delivered at $4.1 \mathrm{msec}$ intervals $(244 \mathrm{~Hz})$. At higher stimulating rates the amplitude of responses decreased. Responses were robust, however, even when shocks were delivered at $1.4 \mathrm{msec}$ intervals $(714 \mathrm{~Hz})$. The latency between the beginning of the shock artifact and the peaks of responses increased during the trains except at the lowest rate. At $476 \mathrm{~Hz}$, the first response had a latency of $1.05 \mathrm{msec}$ while the fifth response had a latency of $1.20 \mathrm{msec}$. At $714 \mathrm{~Hz}$ the eighth response had a latency of $1.35 \mathrm{msec}$. Each trace shows the average of two responses.

potentials are broadened and lack undershoots. These experiments indicate that octopus cells have voltage-dependent $\mathrm{K}$ ' channels and that these channels contribute to the resting potential and shape the action potential. Although these $\mathrm{K}^{+}$channels presumably contributed to the resting conductance, as indicated by the effect of 4-AP on the resting potential, their relative contribution to the input resistance was small and not measurable in our experiments.

In all eight labeled octopus cells tested, the input resistance was raised significantly in the hyperpolarizing voltage range by intracellular and extracellular $\mathrm{Cs}^{+}$, slowing the voltage changes in responses to current. One experiment in which 5,10 , and 15 $\mathrm{mm} \mathrm{CsCl}$ were applied sequentially is illustrated in Figures 12 and 13. Figure 12 shows responses to $0.5 \mathrm{nA}$ hyperpolarizing current pulses under the various conditions. In the absence of $\mathrm{Cs}^{+}$the voltage changes were too rapid for the electrode to be balanced and thus for the input resistance to be measured from the steady-state voltage change during the current pulse. The time course of the hyperpolarization at the onset of hyperpolarizing current pulses was measured in the traces shown in Figure 12. The onset of hyperpolarization could in every case be fit with two exponentials. For each trace, the shorter time constant was between 0.1 and $0.2 \mathrm{msec}$ and did not vary with experi-
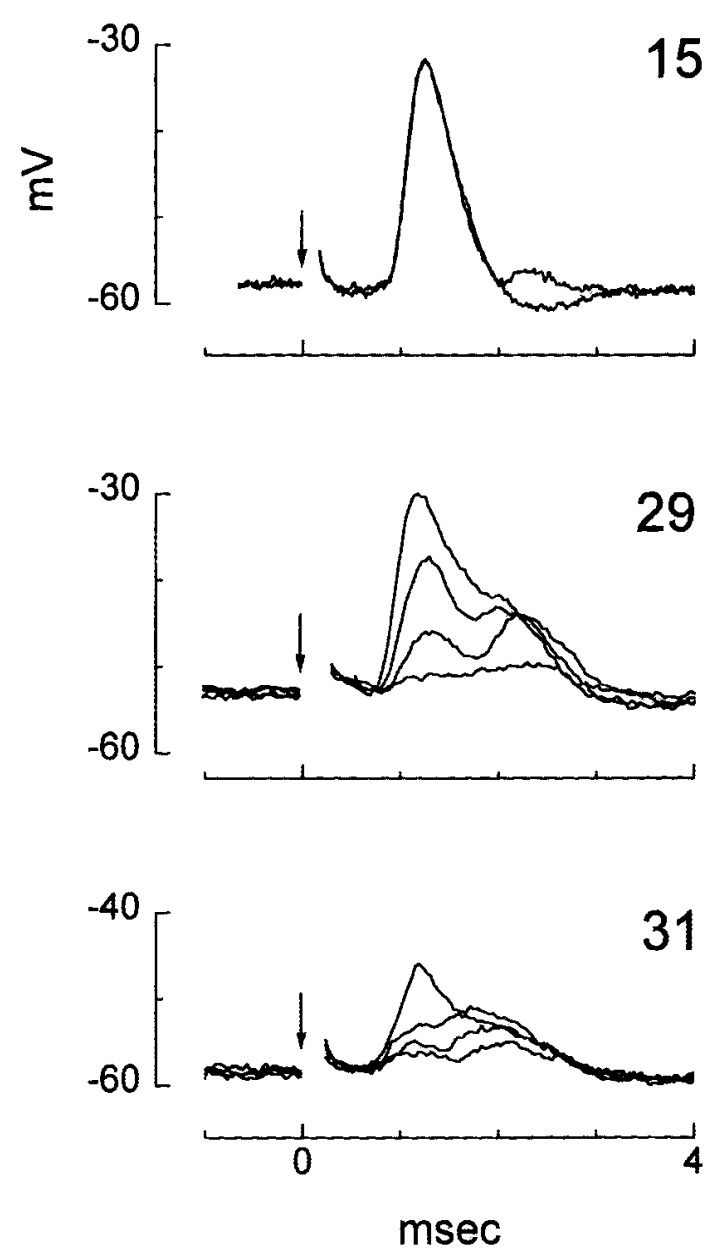

Figure?. Some cells responded to shocks of the auditory nerve with multiple peaks. The first peak represents synaptic excitation by auditory nerve fibers. The increment of 1 msec to the latency of the second peak is consistent with its representing excitation though a disymaptic pathway, possibly through the local collaterals of other octopus cells. The upper panel shows two superimposed traces of responses to $10 \mathrm{~V}$ shocks of cell 15. While in one trace two EPSP were evident, in the other the second EPSP was lacking. The lower panels show four superimposed traces of responses to shocks of variable strength recorded from cells 29 and 31 . In these cells the second responses were consistently robust.

mental condition, therefore presumably reflecting the time constant of the electrode. A second time constant, shown in the figure, varied with experimental condition and thus reflected the properties of the cell. In normal saline before and after the application of $\mathrm{Cs}^{+}$the time constants were roughly $1 \mathrm{msec}$. The time course of voltage changes in responses to current pulses, and therefore the input resistance of the octopus cell, increased roughly 20 fold in the presence of $\mathrm{Cs}^{+}$. The time constants in the presence of 10 and $15 \mathrm{mM} \mathrm{Cs}^{+}$increased, becoming large enough for the bridge to be balanced. After dropping, the voltage sagged back to $-64 \mathrm{mV}$ in $10 \mathrm{~mm}$ and to $-69 \mathrm{mV}$ in $15 \mathrm{~mm}$ $\mathrm{Cs}^{-1}$.

The action of Cs' made it possible to estimate the input resistance of octopus cells from the slopes of voltage-current plots (एig. 13). The plot shows a comparison of the voltage at the end of the current pulse as a function of pulse-strength in $10 \mathrm{~mm}$ $\mathrm{Cs}^{+}$with that in normal saline after $10 \mathrm{~mm} \mathrm{Cs}$ ' was washed out. Within $10 \mathrm{mV}$ of rest, the slope of the plot was $13 \mathrm{M} \Omega$ before 
12
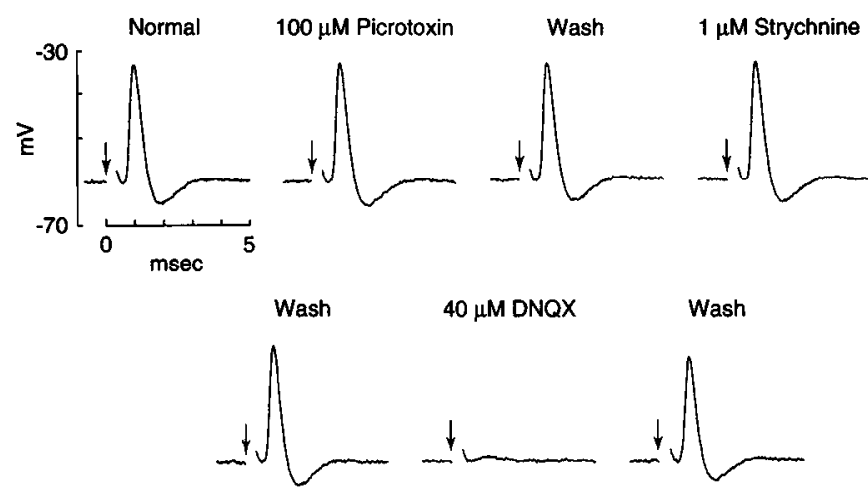

Figure 10. Synaptic responses to shocks of the auditory nerve were unaffected by blockers of glycinergic and GABAergic inhibition; they were blocked by an antagonist of non-NMDA glutamate receptors. All shocks were $5 \mathrm{~V}$. Picrotoxin was applied for $8 \mathrm{~min}$; strychnine was applied for $4 \mathrm{~min}$; DNQX was applied for $4 \mathrm{~min}$.

and $8 \mathrm{M} \Omega$ after $10 \mathrm{mM} \mathrm{Cs}^{+}$was washed out. As there were no corresponding differences in time constants, the difference in slope was insignificant. We conclude that the input resistance of octopus cell 22 in normal saline was roughly $10 \mathrm{M} \Omega$ The pattern of effects of extracellular $\mathrm{Cs}^{+}$illustrated in Figures 12 and 13 was consistent in all six cells tested.

Extracellular $\mathrm{Cs}^{+}$has been shown to block inward rectifiers in other cells (Hagiwara and Takahashi, 1974; Hagiwara et al., 1976; Halliwell and Adams, 1982; Spain et al., 1987; van Ginneken and Giles, 1991; Banks et al., 1993). In octopus cells, as in other cells (Hagiwara et al., 1976; Constanti and Galvan, 1983), the block seems to be voltage dependent because the sag is blocked only with large hyperpolarizations. The finding that the voltage sagged back to -64 or $-69 \mathrm{mV}$, levels more depolarized than expected for $E_{\mathrm{K}}$, suggests that the inward rectifier resembled $I_{h}$ (DiFrancesco, 1981; Halliwell and Adams, 1982; McCormick and Pape, 1990; van Ginneken and Giles, 1991; Banks et al., 1993) more than $I_{\mathrm{K} 1}$ (Hagiwara and Takahashi, 1974; Hagiwara et al., 1976; Oertel et al., 1978; Constanti and Galvan, 1983; Kubo et al., 1993).

Intracellular iontophoresis of cesium acetate through the recording electrode also increased the input resistance and timc constant of the two octopus cells tested (data not shown). The finding that the input resistance can be raised by blocking bio- logical conductances indicates that the low input resistances of octopus cells are not experimental artifacts of the impalement.

In an attempt to block as much of the resting conductance as possible, one recording was made with a microelectrode that contained $2 \mathrm{M}$ cesium acetate and both $15 \mathrm{mM} \mathrm{Cs}^{+}$and $2 \mathrm{~mm}$ 4-AP were applied in the bath (Fig. 14). Under these conditions, an all-or-none, regenerative event could be evoked with depolarizing current. The specificity of the blockers for potassium channels and mixed cation, inward rectifier channels makes it unlikely that the blockers affect the regenerative, depolarizing currents directly but enhances their activation by reducing opposing currents. The voltage-current relationship was approximately linear in the hyperpolarizing voltage range with a slope of $50 \mathrm{M} \Omega$ Action potentials could only be evoked singly under all tested conditions.

\section{Potassium conductances influence the waveform of evoked synaptic responses}

TEA, 4-AP, and $\mathrm{Cs}^{+}$changed the waveform of responses to shocks of the auditory nerve in octopus cells, as would be expected from their actions as blockers of potassium conductances, but these changes resulted at least in part presynaptically. These blockers act not only on octopus cells but probably also on synaptic terminals (Katz and Miledi, 1967; Heuser et al., 1979; Lindgren and Moore, 1989; Bielefeldt et al., 1992; Hayashi and Stuart, 1993). The addition of 2 or $4 \mathrm{mM} \mathrm{4-AP}$ to the bathing mcdium induced frequent, spontaneous EPSPs; after the barrage of spontaneous synaptic input died down, 4-AP, like TEA and $\mathrm{Cs}^{+}$, increased the duration and amplitude of the synaptic responses of octopus cells and eliminated the afterhyperpolarization (Fig. 15). The elimination of the afterhyperpolarization was not an indirect consequence of depolarization, as hyperpolarization of the cell with current did not restore the presence of the afterhyperpolarization. The afterhyperpolarization in octopus cells is likely to be a consequence of the activation of one or more voltage-dependent, $\mathrm{K}^{+}$conductances which contribute to the short duration of EPSPs in octopus cells.

\section{Discussion}

Octopus cells detect coincident firing within populations of auditory nerve fibers and convey acoustic information in precisely timed action potentials. In duration, the EPSPs of octopus cells arc among the bricfest recordcd in any cell. Synaptic potentials can be brief because the input resistances of octopus cells are low and allow voltage changes to be rapid. The same mecha-

\section{1}

Figure 11. The shape of action potentials is affected by 4-aminopyridine (4$A P)$. Anode break action potentials were evoked at the offset of $-1.4 \mathrm{nA}$ hyperpolarizing current pulses in cell 21 , which was impaled with a $\mathrm{Cs}^{+}$containing microelectrode. Bath-application of $2 \mathrm{~mm}$ 4-AP depolarized the cell by $8 \mathrm{mV}$ and eliminated the undershoot after the action potential even when the cell was repolarized with current to the original resting potential; $40 \mu \mathrm{M}$ DNQX was added together with 4-AP to eliminate synaptic input. The effects of 4-AP were reversible. Each trace is the average of 50 responses.

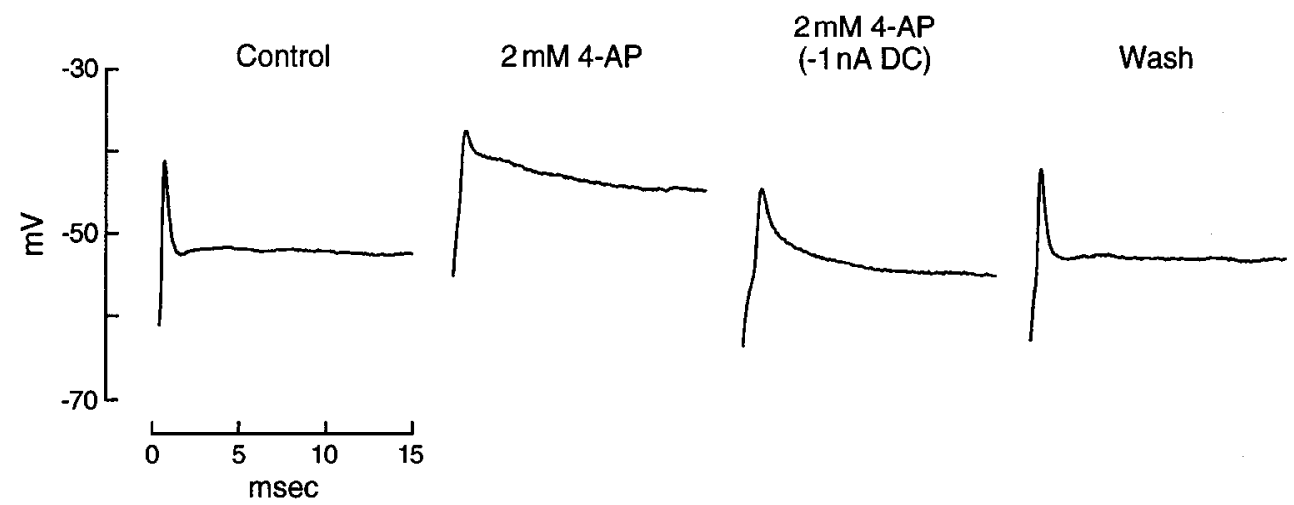




\section{2}

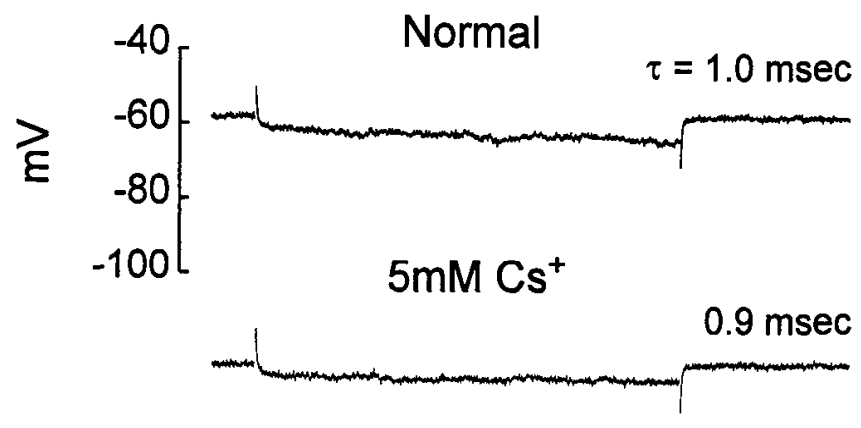

Wash

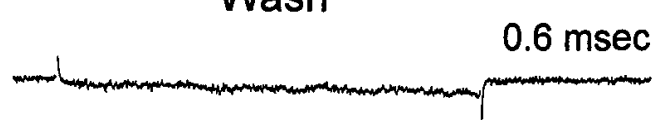

$10 \mathrm{mM} \mathrm{Cs}^{+}$

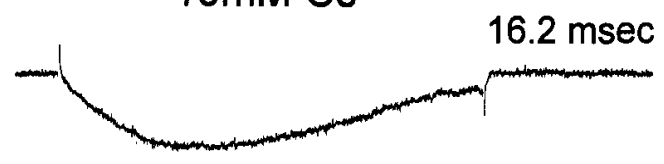

Wash

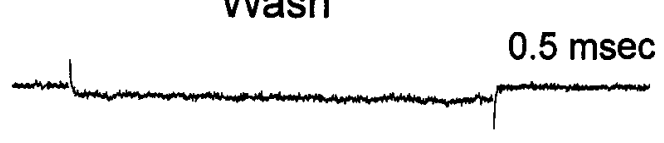

$15 \mathrm{mM} \mathrm{Cs}^{+}$

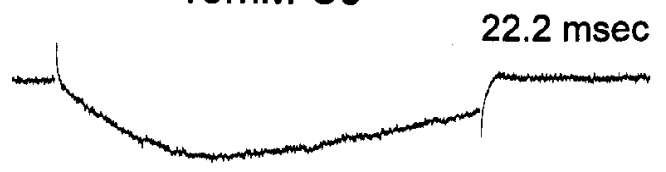

Wash
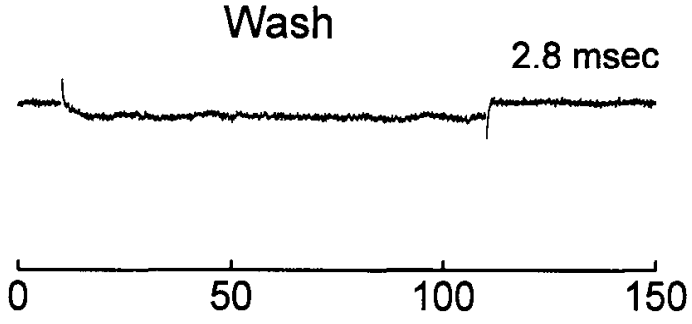

msec

Figure 12. Extracellular $\mathrm{Cs}^{+}$increased the time constant, $\tau$, of responses to $0.5 \mathrm{nA}$ hyperpolarizing current pulses about 20 -fold in octopus cell $22 . \mathrm{Cs}^{+}$was applied sequentially at various concentrations with intervening washes while the cell's input resistance was monitored with responses to current pulses. The first $7 \mathrm{msec}$ after the onset of hyperpolarization were fit with double exponentials for most traces; in the presence of 10 and $15 \mathrm{mM} \mathrm{Cs}^{+}$the first $30 \mathrm{msec}$ were used to fit double exponentials. The transients at the onset and offset of the current pulses werc truncated for clarity of the figure, but not for measuring nisms that allow octopus cells to carry timing information precisely, cause action potentials to be attenuated at the cell body where our recordings were probably most often made.

Octopus cells in slices from mice, as elsewhere, have large dendrites that spread across the bundles of auditory nerve fibers (Adams, 1986, humans; Osen, 1969; Kane, 1973; Brawer et al., 1974; Rhode et al., 1983, cats; Willard and Ryugo, 1983; Oertel et al., 1990; Willott and Bross, 1990, mice; Disterhoft, 1980, rabbits; Hackney et al., 1990, guinea pigs; Morest et al., 1990, chinchillas). A new finding is that the axons of octopus cells in mice terminate within the octopus cell area, in the deep layer of the dorsal cochlear nucleus, as well as in the granule cell lamina and superficial granule cells. The densest of the local projections is to the octopus cell area. This projection probably corresponds to that described by Warr to what he named the interstitial nucleus of the stria of Held (Warr, 1969, 1972) and to the local projections of presumed octopus cells (Friauf and Ostwald, 1988, category II). Terminals of octopus cells were also associated with the granule cell lamina and superficial granule cells (Mugnaini et al., 1980). In two cases axon collaterals reached into the deep layer of the DCN.

Auditory nerve fibers provide a major source of excitatory input to octopus cells. The descending branches of auditory nerve fibers converge in the octopus cell area (Osen, 1969, 1970; Kane, 1973; Brawer et al., 1974; Godfrey et al., 1975; Lorente de Nó, 1981; Willott and Bross, 1990). Input from the cochlea is through the large, myelinated, type I fibers; small, unmyelinated, type II fibers pass near, but do not innervate, octopus cells (Berglund and Brown, 1994). In cats the octopus cell area is innervated by small boutons from type I fibers with high spontaneous firing rates (Liberman, 1993). On the basis of electron microscopical studies after cochlear ablation in cats it has been suggested that two of the four types of terminals that contact octopus cells arise from the cochlea and two from the superior olivary complex (Kane, 1973, 1977; Schwartz and Kane, 1977). One type of ending presumably arises from type I auditory nerve fibers. Our results raise the possibility that the second terminal type ascribed by Kane to cochlear input arose, instead, from octopus cells.

The auditory nerve of outbred mice contains about 10,000 myelinated afferent fibers (Ehret, 1979). Willott and Bross (1990) have estimated the number of octopus cells in CBA/J mice to be 200 . If every myelinated auditory nerve fiber were to terminate on one octopus cell, octopus cells would receive input from about 50 fibers. As auditory nerve fibers probably contact multiple octopus cells the convergence is likely to be considerably higher. Recordings in vivo which show that octopus cells are broadly tuned support this conclusion (Godfrey et al., 1975; Rhode et al., 1983; Rhode and Smith, 1986; Joris et al., 1992). We have suggested that a small proportion of those inputs is required to bring octopus cells to threshold when auditory nerve fibers are activated synchronously with shocks. In responses to sound, under conditions when auditory nerve fibers

$\leftarrow$

time constants. For every trace, one exponential had a short time constant, between 0.1 and $0.2 \mathrm{msec}$, that presumably was associated with the microelectrode. The second time constant varied with experimental condition and is shown for each trace. In the presence of 10 and $15 \mathrm{~mm}$ $\mathrm{Cs}^{+}$the voltage fell slowly and then sagged back toward rest and repolarization after the end of the pulse was rapid. Excitatory synaptic input during the application of $\mathrm{Cs}^{+}$was blocked with $40 \mu \mathrm{M}$ DNQX. 


\section{2}

\section{$10 \mathrm{mM} \mathrm{Cs}^{+}$}
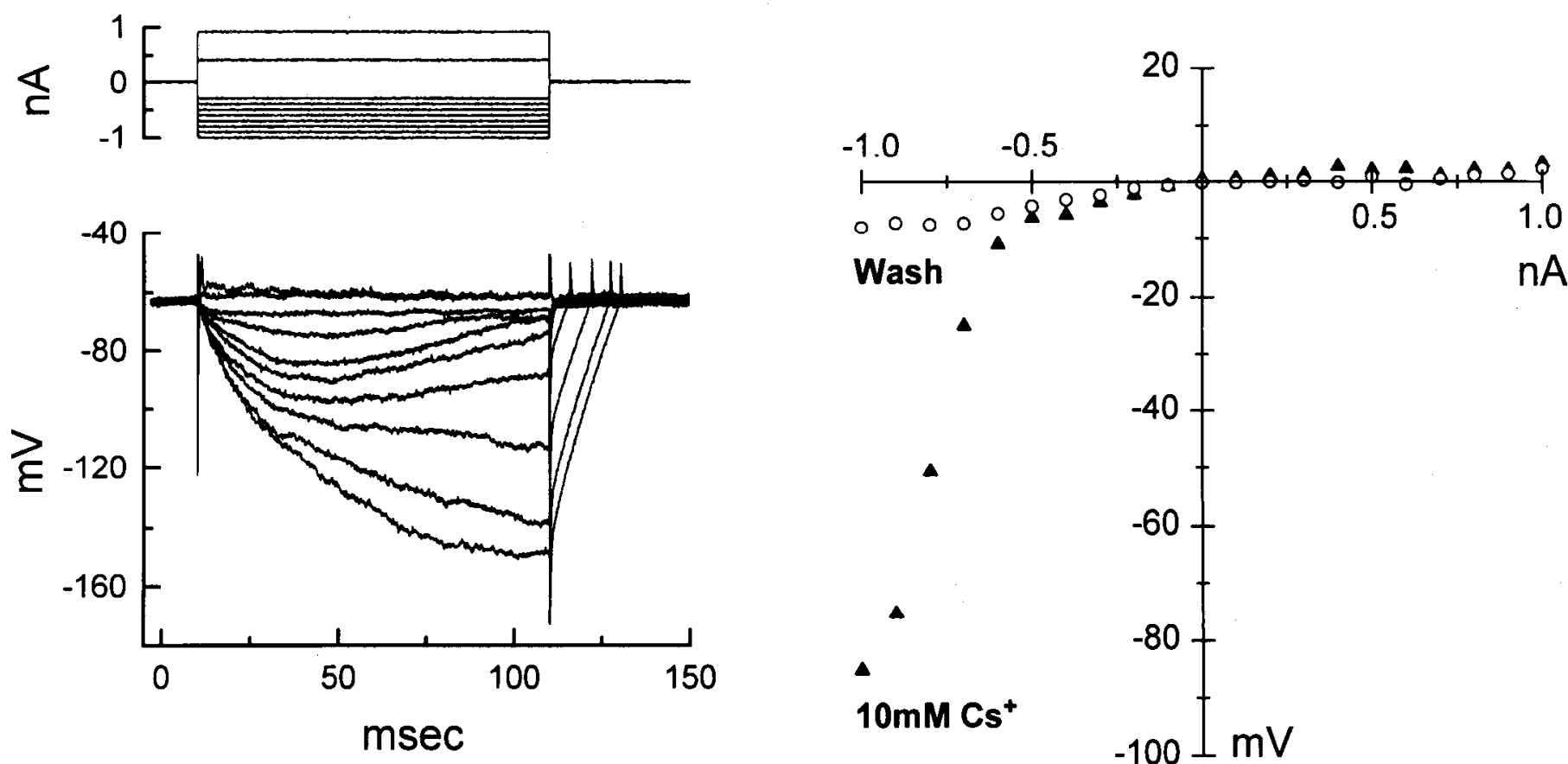

Figure 13. Voltage-current relationships in the presence and absence of $\mathrm{Cs}^{+}$. Left, Hyperpolarizing current pulses produced large, slow voltage changes when $10 \mathrm{mM} \mathrm{Cs}^{+}$was added to the bath. Right, Voltage change at the end of the 100 msec pulse as a function of injected current. Triangles denote measurements in $10 \mathrm{~mm} \mathrm{Cs}{ }^{+}$from traces that include those on the left. The high input resistance allowed the bridge to be balanced. Circles denote measurements during the wash in normal saline after the $10 \mathrm{mM} \mathrm{Cs}^{+}$had been washed out.

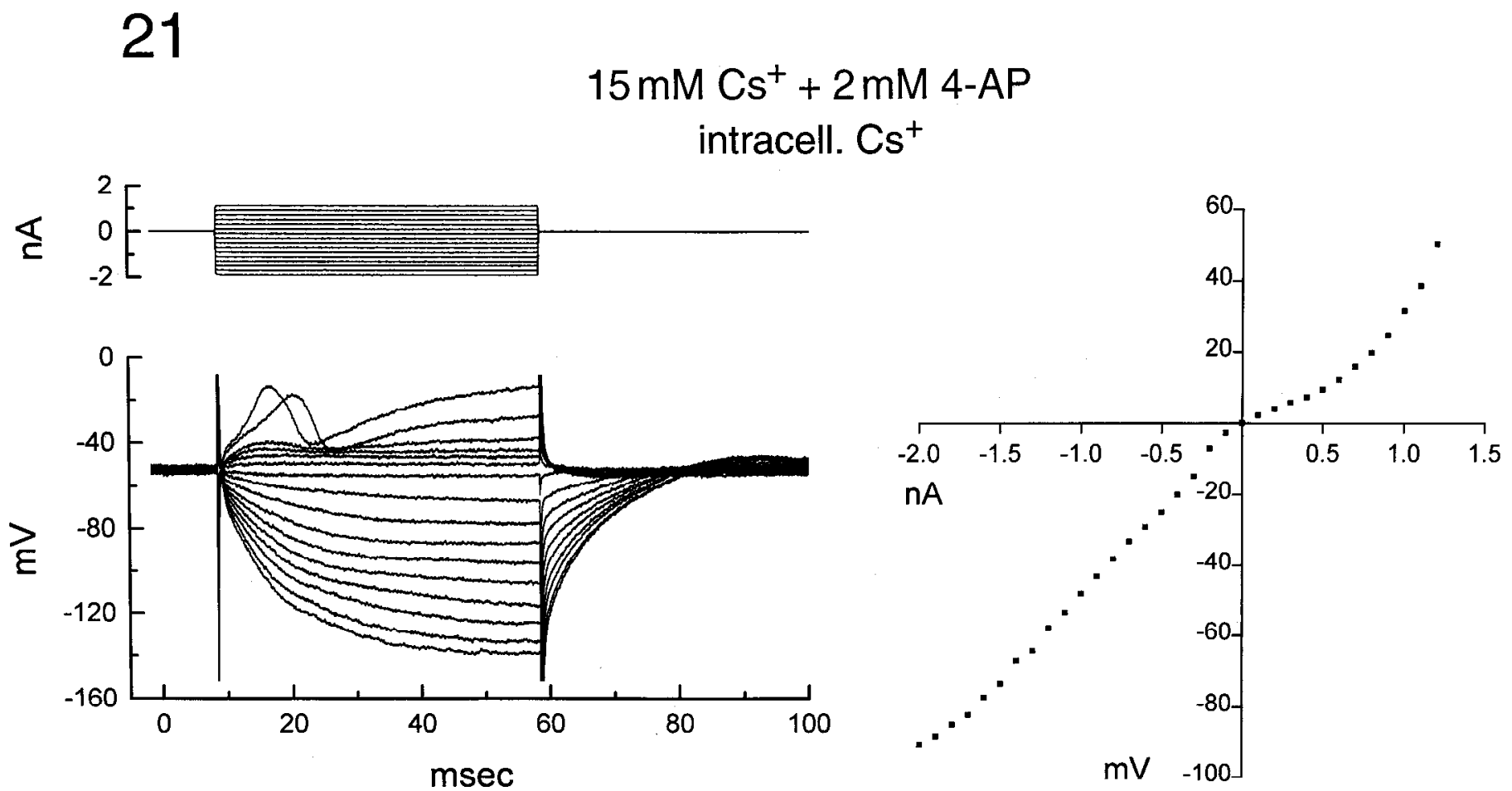

Figure 14. Voltage-current relationship of cell 21 which was impaled with a $\mathrm{Cs}^{+}$-containing microelectrode and then was bathed in saline that contained $15 \mathrm{~mm} \mathrm{Cs}^{+}$and $2 \mathrm{~mm} 4-\mathrm{AP}$ as well as $40 \mu \mathrm{M}$ DNQX. Individual traces are shown on the left. The voltage-current relationship measured at the end of the $50 \mathrm{msec}$ pulses is shown on the right. 

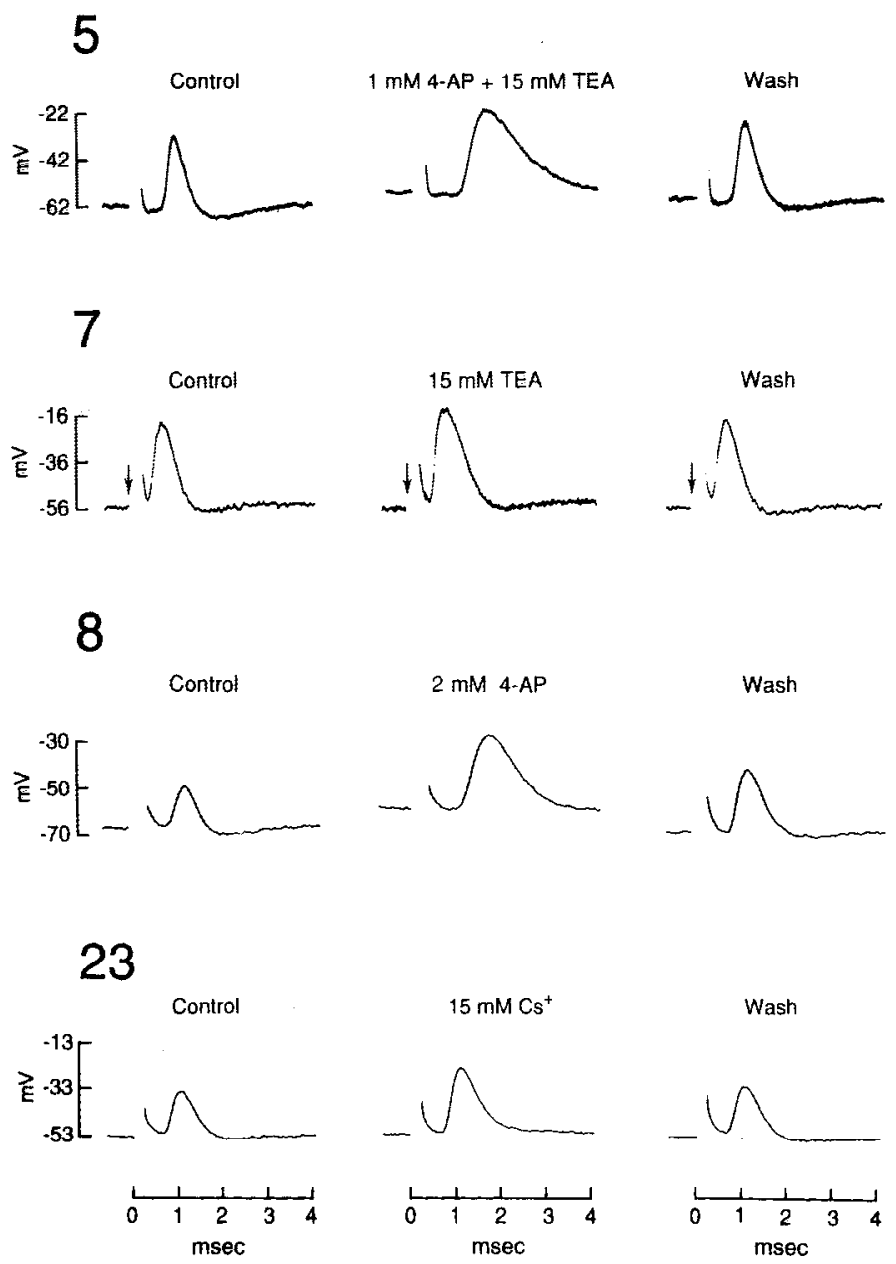

Figure 15. 4-AP. TEA, and $\mathrm{Cs}^{-1}$ reversibly increased the amplitude and duration of synaptic responses and removed the afterhyperpolarization. Of these drugs, only 4-AP depolarized the cells.

are presumably activated less synchronously, a larger proportion of inputs would be required to cause octopus cells to fire.

Input from the auditory nerve is mediated largely through AMPA glutamate receptors in all vertebrates (Wenthold and Martin, 1984; Wickesberg and Oertel, 1989; Raman and Trussell, 1992; Hunter et al., 1993; Zhang and Trussell, 1994). We observed only excitation through AMPA receptors in responses to shocks of the nerve.

The absence of strychnine-sensitive inhibition is consistent with the finding that there are few, if any, glycinergic terminals in the octopus cell arca of mice (Wickesberg ct al., 1991). In rats, the octopus cell area also shows a dearth of glycine-positive puncta (Osen, personal communication). In cats (Wenthold, 1987) and guinea pigs (Wenthold et al., 1987; St. Marie et al., 1991) puncta labeled by antibodies against glycine conjugates have, however, been reported to be present. Puncta labeled with antibodies to GABA conjugates and to GAD are also present around octopus cells (Adans and Mugnaini, 1987; St. Marie et al., 1989). These puncta could correspond to one of the two sources of input from the superior olivary complex (Kane, 1973, 1977; Schwartz and Kane, 1977). Octopus cells differed from other cells in the cochlear nuclei in slices in that IPSPs were absent (Wu and Oertel, 1986; Hirsch and Oertel, 1988; Oertel and Wickesberg, 1993).

All 34 identified octopus cells have low input resistances and small action potentials. These unusual properties in our slices raise the question whether the low input resistances might reflect experimental artifacts arising from the slice preparation or from the impalement. Low input resistances, short time constants and high thresholds are often indications that cells are damaged. We consider it likely that these recordings from octopus cells reflect the properties of normal octopus cells for the following reasons. First, the finding was consistent in all 34 octopus cells. Second, the recordings from these cells were stable for several hours and had resting potentials that resembled those of other cells in the cochlear nuclei. Third, the histology of labeled and unlabeled octopus cells in most slices resembled that of octopus cells in tissue fixed in situ and labeled with cresyl violet or with the Golgi technique (Willard and Ryugo, 1983; Willott and Bross, 1990). Fourth, cells that were not octopus cells had conventional properties in the sante slices. Fifth, extracellular $\mathrm{Cs}^{\text {* blucked a }}$ large proportion of the conductance in the hyperpolarizing voltage range indicating that the input resistance did not result from a nonspecific leak. Sixth, the present results are consistent with extracellular recordings from octopus cells in vivo. The finely graded, precisely timed EPSPs are what would be expected from cells that have broad tuning curves, responses to tones with sharp onset peaks, and precisely timed responses to clicks (Godfrey et al., 1975; Joris et al., 1992; Smith et al., 1993).

One conductance that probably contributes to the low input resistance of octopus cells is an inward rectifier. Two types of inward rectifiers have been described, both of which are blocked by $\mathrm{Cs}^{*}$. One, $I_{t i}$, results from a mixed cation conductance with a reversal potential in the range of -25 to $-60 \mathrm{mV}$ and has been described in muscle and in neurons of the hippocampus, thalamus, and brainstem (DiFrancesco, 1981; Halliwell and Adams, 1982; McCormick and Pape, 1990; van Ginneken and Giles, 1991; Banks et al., 1993). Another, $I_{k 1}$, results from a conductance specific for $\mathrm{K}^{+}$and is dependent on the electrochemical gradient and has been described in starfish eggs, Paramecium, olfactory neurons, and heart muscle (Hagiwara and Takahashi, 1974; Hagiwara et al., 1976; Oertel et al., 1978; Constanti and Galvan, 1983; Kubo et al., 1993). As in other cells, the block by $\mathrm{Cs}^{+}$seems to be voltage dependent (Hagiwara et al., 1976; Constanti and Galvan, 1983). If $E_{\mathrm{K}}$ in octopus cells lies in the range between -80 and $-95 \mathrm{mV}$, as is common in other mammalian neurons, the sag toward $-70 \mathrm{mV}$ observed in octopus cells in the presence of $\mathrm{Cs}^{+}$indicates that the inward rectifier results from a mixed conductance rather than a $\mathrm{K}^{+}$conductance and thus resembles $I_{h}$ more than $I_{\mathrm{K} 1}$. In support of this conclusion is the finding that $\mathrm{CS}^{+}$, in contrast with 4-AP, did not affect the resting potential.

Low input resistances have two functionally important consequences in the signaling of octopus cells. First, low input resistances allow synaptic potentials to be rapid and brief, contributing to the precision in timing discussed above. Second, low input resistances cause voltage changes in responses to synaptic currents to be small. Because the contributions of individual inputs are small and subthreshold, octopus cells serve as coincidence detectors for auditory nerve fibers. Such an interpretalion is consistent with intracellular recordings from "on" units (Romand, 1978; Feng et al., 1994).

While the usefulness of binaural coincidence detectors has long been appreciated, as for example in the Jeffress model for sound localization, the function of monaural coincidence detection has received less attention. Delgutte and Cariani (1992) have recorded responses to harmonic complexes, including some 
that evoke clear pitch sensations and others that have ambiguous pitches, from populations of auditory nerve fibers. They find that the period of pitch judgements in human beings corresponds to the most probable interspike intervals in the population of auditory nerve fibers in cats (Delgutte and Cariani, 1992). Octopus cells are suited to detect common interspike intervals in auditory nerve fibers and might therefore encode pitch period in their temporal firing patterns.

\section{References}

Adams JC (1981) Heavy metal intensification of DAB-based HRP reaction product. J Histochem Cytochem 29:775.

Adams JC (1986) Neuronal morphology in the human cochlear nucleus. Arch Otolaryngol 112:1253-1261.

Adams JC, Mugnaini E (1987) Patterns of glutamate decarboxylase immunostaining in the feline cochlear nucleus complex studied with silver enhancement and electron microscopy. J Comp Neurol 262: 375-401.

Adams JC, Warr WB (1976) Origins of axons in the cat's acoustic striae determined by injection of horseradish peroxidase into severed tracts. J Comp Neurol 170:107-122.

Banks MI, Pearce RA, Smith PH (1993) Hyperpolarization-activated cation current $\left(I_{h}\right)$ in neurons of the medial nucleus of the trapezoid body: voltage-clamp analysis and enhancement by norepinephrine and CAMP suggest a modulatory mechanism in the auditory brainstem. J Neurophysiol 70:1420-1432.

Berglund AM, Brown MC (1994) Central trajectories of type 11 spiral ganglion cells from various cochlear regions in mice. Hearing Res 75:121-130.

Bielefeldt K, Rotter JL, Jackson MB (1992) Three potassium channels in rat posterior pituitary nerve terminals. J Physiol (Lond) 458:4167.

Blackstad TW, Osen KK, Mugnaini E (1984) Pyramidal neurones of the dorsal cochlear nucleus: a Golgi and computer reconstruction study in cat. Neuroscience 13:827-854.

Brawer JB, Morest DK, Kane EC (1974) The neuronal architecture of the cochlear nucleus of the cat. J Comp Neurol 155:251-300.

Brown MC, Ledwith JV III (1990) Projections of thin (type-II) and thick (type-I) auditory-nerve fibers into the cochlear nucleus of the mouse. Hearing Res 49:105-118.

Choi DW, Fischbach GD (1981) GABA conductance of chick spinal cord and dorsal root ganglion neurons in cell culture. $\mathbf{J}$ Neurophysiol 45:605-620.

Constanti A, Galvan M (1983) Fast inward-rectifying current accounts for anomalous rectification in olfactory cortex neurones. J Physiol (Lond) 385:153-178.

Delgutte B, Cariani P (1992) Coding of the pitch of harmonic and inharmonic complex tones in the interspike intervals of auditorynerve fibers. In: Auditory processing of speech, from sounds to words (Schouten MEH, ed), pp 37-45. New York: Mouton de Gruyter.

DiFrancesco D (1981) A study of the ionic nature of the pace-maker current in calf Purkinjc fibres. J Physiol (Lond) 314:377-393.

Disterhoft JF, Perkins RE, Evans S (1980) Neuronal morphology of the rabbit cochlear nucleus. J Comp Neurol 192:687-702.

Ehret G (1979) Quantitative analysis of nerve fibre densities in the cochlea of the house mouse (Mus musculus). J Comp Neurol 183: 73-88.

Feng J, Kuwada S, Ostapoff E-M, Batra R, Morest DK (1994) A physiological and structural study of neuron types in the cochlear nucleus. I. Intracellular responses to acoustic stimulation and current injection. J Comp Neurol 346:1-18.

Friauf E, Ostwald J (1988) Divergent projections of physiologically characterized rat ventral cochlear nucleus neurons as shown by intraaxonal injection of horseradish peroxidase. Exp Brain Res 73:263284.

Godfrey DA, Kiang NYS, Norris BE (1975) Single unit activity in the posteroventral cochlear nucleus of the cat. J Comp Neurol 162:247268.

Hackney CM, Osen KK, Kolston J (1990) Anatomy of the cochlear nuclear complex of guinea pig. Anat Embryol (Berl) 182:123-149.

Hagiwara S, Takahashi K (1974) The anomalous rectification and cation selectivity of the membrane of a starfish egg cell. J Membr Biol $18: 61-80$.
Hagiwara S, Miyazaki S, Rosenthal NP (1976) Potassium current and the effect of cesium on this current during anomalous rectification of the egg cell membrane of a starfish. J Gen Physiol 67:621-638.

Halliwell JV, Adams PR (1987) Voltage-clamp analysis of muscarinic excitation in hippocampal neurons. Brain Res 250:71-92.

Hayashi JH, Stuart AE (1993) Currents in the presynaptic terminal arbors of barnacle photoreceptors. Visual Neurosci 10:261-270.

Heuser JE, Reese TS, Dennis MJ, Jan Y, Jan L, Evans L (1979) Synaptic vesicle exocytosis captured by quick freezing and correlated with quantal transmitter release. J Cell Biol 81:275-300.

Hille B (1967) The selective inhibition of delayed potassium currents in nerve by tetraethylammonium ion. J Gen Physiol 50:1287-1302.

Hirsch JA, Oertel D (1988) Synaptic connections in the dorsal cochlear nucleus of mice, in vitro. J Physiol (Lond) 396:549-562.

Honoré T, Davies SN, Drejer J, Fletcher EJ, Jacobsen P, Lodge D, Nielsen FE (1988) Quinoxalinediones: potent competitive non-NMDA glutamate receptor antagonists. Science 241:701-703.

Horikawa K, Armstrong WE (1988) A versatile means of intracellular labeling: injection of biocytin and its detection with avidin conjugates. J Neurosci Methods 25:1-11.

Hunter C, Petralia RS, Vu T, Wenthold RJ (1993) Expression of AMPA-selective glutamate receptor subunits in morphologically defined neurons of the mammalian cochlear nucleus. J Neurosci 13: $1932-1946$.

Joris PX, Smith PH, Yin TCT (1992) Responses and projections of dorsal and intermediate stria axons labelled with HRP or Neurobiotin. Assoc Res Otolaryngol Abstr 15:58.

Kane EC (1973) Octopus cells in the cochlear nuclei of the cat: heterotypic synapses upon homeotypic neurons. Int J Neurosci 5:251279.

Katz B, Miledi R (1967) A study of synaptic transmission in the abscnce of nerve impulses. J Physiol (Lond) 192:407-436.

King MA, Louis PM, Hunter BE, Walker DW (1989) Biocytin: a versatile anterograde neuroanatomical tract-tracing alternative. Brain Res 497:361-367.

Kubo Y, Baldwin TJ, Jan YN, Jan LY (1993) Primary structure and functional expression of a mouse inward rectifier potassium channel. Nature 362:127-133.

Leake PA, RL Snyder RL (1989) Topographic organization of the central projections of the spiral ganglion in cats. I Comp Nelurol 281 : 612-629.

Liberman MC (1993) Central projections of auditory-nerve fibers of differing spontaneous rate. II. Posteroventral and dorsal cochlear nuclei. J Comp Neurol 327:17-36.

Lindgren CA, Moore JW (1989) Identification of ionic currents at presynaptic nerve endings of the lizard. J Physiol (Lond) 414:201-222.

Lorente de Nó R (1981) The primary acoustic nuclei. New York: Raven.

Manis PB, Marx SO (1991) Outward currents in isolated ventral cochlear nucleus neurons. J Neurosci 11:2865-2880.

McCormick DA, Pape HC (1990) Properties of a hyperpolarizationactivated cation current and its role in rhythmic oscillation in thalamic relay neurons. J Physiol (Lond) 431:291-318.

Morest DK, Hutson KA, Kwok S (1990) Cytoarchitectonic atlas of the cochlear nucleus of the chinchilla, Chinchilla laniger. J Comp Neurol 300:230-248.

Mugnaini E, Warr WB, Osen KK (1980) Distribution and light microscopic features of granule cells in the cochlear nuclei of cat, rat, and mouse. J Comp Neurol 191:581-606.

Oertel D (1985) Use of brain slices in the study of the auditory system: spatial and temporal summation of synaptic inputs in cells in the anteroventral cochlear nucleus of the mouse. J Acoust Soc Am 78: 328-333.

Oertel D, Wickesberg RE (1993) Glycinergic inhibition in the cochlear nuclei: evidence for tuberculoventral neurons being glycinergic. In: The mammalian cochlear nuclei: organization and function (Merchan MA, Juiz JM, Godfrey DA, Mugnaini E, eds), pp 225-237. New York: Plenum.

Oertel D, Wu SH (1989) Morphology and physiology of cells in slice preparations of the dorsal cochlear nucleus of mice. J Comp Neurol 283:228-247.

Oertel D, Schein SJ, Kung C (1978) A potassium conductance activated by hyperpolarization in Paramecium. J Membr Biol 43:169185.

Oertel D, Wu SH, Garb MW, Dizack C (1990) Morphology and phys- 
iology of cells in slice preparations of the posteroventral cochlear nucleus of mice. J Comp Neurol 295:136-154.

Osen KK (1969) Cytoarchitecture of the cochlear nuclei in the cat. J Comp Neurol 136:453-484.

Osen KK (1970) Course and termination of the primary afferents in the cochlear nuclei of the cat. Arch Ital Biol 108:21-51.

Raman IM, Trussell LO (1992) The kinetics of the response to glutamate and kainate in neurons of the avian cochlear nucleus. Neuron 9:173-186

Rhode WS, Smith PH (1986) Encoding timing and intensity in the ventral cochlear nucleus of the cat. J Neurophysiol 56:261-286.

Rhode WS, Oertel D, Smith PH (1983) Physiological response properties of cells labelled intracellularly with horseradish peroxidase in cat ventral cochlear nucleus. J Comp Neurol 213:448-463.

Romand R (1978) Survey of intracellular recording in the cochlear nucleus of the cat. Brain Res 148:43-65.

Rose JE, Galambos R, Hughes JR (1959) Microelectrode studies of the cochlear nuclei of the cat. Bull Johns Hopkins Hospital 104:211251.

Rouiller EM, Ryugo DK (1984) Intracellular marking of physiologically characterized cells in the ventral cochlear nucleus of the cat. J Comp Neurol 225:167-186.

Sachs MB, Abbas PJ (1974) Rate versus level functions for auditorynerve fibers in cats: tone-burst stimuli. J Acoust Soc Am 56:18351847.

Saint Marie RL, Morest DK, Brandon CJ (1989) The form and distribution of GABAergic synapses on the principal cell types of the ventral cochlear nucleus of the cat. Hearing Res 42:97-112.

Saint Marie RL, Benson CG, Ostapoff EM, Morest DK (1991) Glycine immunoreactive projections from the dorsal to the anteroventral cochlear nucleus. Hearing Res 51:11-28.

Schwartz AM, Kane EC (1977) Development of the octopus cell area in the cat ventral cochlcar nuclcus. Am J Anat 148:1-18.

Smith PH, Joris PX, Banks MI, Yin TCT (1993) Responses of cochlear nucleus cells and projections of their axons. In: The mammalian cochlear nuclei: organization and function (Merchan MA, Juiz JM, Godfrey DA, Mugnaini E, eds), pp 349-360, New York: Plenum.

Spain WJ, Schwindt PC, Crill WE (1987) Anomalous rectification in neurons from cat sensorimotor cortex in vitro. J Neurophysiol 57: $1555-1576$.

Van Ginneken ACG, Giles W (1991) Voltage clamp measurements of the hyperpolarization-activated inward current $I_{f}$ in single cells from rabbit sino-atrial node. J Physiol (Lond) 434:57-83.

Warr WB (1969) Fiber degeneration following lesions in the posteroventral cochlear nucleus of the cat. Exp Neurol 23:140-155.

Warr WB (1972) Fiber degeneration following lesions in the multipolar and globular ecll areas in the ventral cochlcar nucleus of the cat. Brain Res 40:247-270.

Warr WB (1982) Parallel ascending pathways from the cochlear nucleus: neuroanatomical evidence of functional specialization. In: Con- tributions to sensory physiology, Vol 7, pp 1-38. New York: Academic.

Wenthold RJ (1987) Evidence for a glycinergic pathway connecting the two cochlear nuclei: an immunocytochemical and retrograde transport study. Brain Rcs 415:183-187.

Wenthold RJ, Martin MR (1984) Neurotransmitters of the auditory nerve and central auditory system. In: Hearing science (Berlin CI, ed), pp 341-370. San Diego: College-Hill.

Wenthold RJ, Huie D, Altschuler RA, Reeks KA (1987) Glycine immunoreactivity localized in the cochlear nucleus and superior olivary complex. Neuroscience 22:897-912.

Wickesberg RE, Oertel D (1988) Tonotopic projection from the dorsal to the anteroventral cochlear nucleus of mice. J Comp Neurol 268: 389-399.

Wickesberg RE, Oertel D (1989) Auditory nerve neurotransmitter acts on a kainate receptor: evidence from intracellular recordings in brain slices from mice. Brain Res 486:39-48.

Wickesberg RE, Whitlon D, Oertel D (1991) Tuberculoventral neurons project to the multipolar cell area but not to the octopus cell area of the posteroventral cochlear nucleus. J Comp Neurol 313:457-468.

Willard FH, Ryugo DK (1983) Anatomy of the central auditory system. In: The auditory psychobiology of the mouse (Willott JF, ed), pp 201304. Springfield, MA: Thomas.

Willott JF, Bross LS (1990) Morphology of the octopus cell area of the cochlear nucleus in young and aging $\mathrm{C} 57 \mathrm{BL} / 6 \mathrm{~J}$ and $\mathrm{CBA} / \mathrm{J}$ mice. J Comp Neurol 300:61-81.

Wu SH, Oertel D (1984) Intracellular injection with horseradish peroxidase of physiologically characterized stellate and bushy cells in slices of mouse anteroventral cochlear nuclei. J Neurosci 4:15771588.

Wu SH, Oertel D (1986) Inhibitory circuitry in the ventral cochlear nucleus is probably mediated by glycine. J Neurosci 6:2691-2706.

Ych JZ, Oxford GS, Wu CH, Narahashi T (1976) Dynamics of aminopyridine block of potassium channels in squid axon membrane. $\mathbf{J}$ Gen Physiol 68:519-535.

Zhang S, Oertel D (1993a) Cartwheel and superficial stellate cells of the dorsal cochlear nucleus of mice: intracellular recordings in slices. J Neurophysiol 69:1384-1397.

Zhang S, Oertel D (1993b) Giant cells of the dorsal cochlear nucleus of mice: intracellular recordings in slices. J Neurophysiol 69:1398 1408.

Zhang S, Oertel D (1993c) Tuberculoventral cells of the dorsal cochlear nucleus of mice: intracellular

recordings in slices. J Neurophysiol 69:1409-1421.

Zhang S, Oertel D (1994) Neuronal circuits associated with the output of the dorsal cochlear nucleus through fusiform cells. J Neurophysiol 71:914-930.

Zhang S, Trussell LO (1994) A characterization of excitatory postsynaptic potentials in the avian nucleus magnocellularis. J Neurophysiol 72:705-718. 